\title{
Wages, Profits, and Macroeconomic Adjustment: A Comparative Study
}

THE BEHAVIOR of real wages has complicated macroeconomic policy in the industrialized world during the 1970s. Many commentators have discussed the extraordinary increase in wage inflation in Europe and Japan at the end of the last decade. ${ }^{1}$ Few have noted that the nominal wage gains resulted in remarkable increases in real wages. The five large economies outside North America in the Organisation for Economic Cooperation and Development (OECD) had rapid growth of real hourly compensation in 1969-73, along with high rates of increase of nominal compensation. In most large $\mathrm{OECD}$ economies, real wages in the late 1960s grew faster than productivity, so that the distribution of income shifted toward labor, while the rate of return on capital was substantially reduced.

1. For a thorough econometric study, see George L. Perry, "Determinants of Wage Inflation around the World," BPEA, 2:1975, pp. 403-35. Another important study that focuses largely on the 1969-76 period is Robert J. Gordon, "World Inflation and Monetary Accommodation in Eight Countries," BPEA, 2:1977, pp. 409-68. Further evidence for extraordinary wage behavior in the late 1960s is provided by Erich Spitaller, "Semi-Annual Wage Equations for the Manufacturing Sectors in Six Major Industrial Countries," Weltwirtschaftliches Archiv, vol. 112, no. 2 (1976), pp. 300-37. In addition, from a vast sociological literature that focuses on wages and trade union behavior in the late 1960s, see the collections of essays in Solomon Barkin, ed., Worker Militancy and Its Consequences, 1965-75: New Directions in Western Industrial Relations (Praeger, 1975); and Colin Crouch and Alessandro Pizzorno, eds., The Resurgence of Class Conflict in Western Europe Since 1968, vol. 1: National Studies, and vol. 2: Comparative Analyses (Holmes and Meier, 1978). 
In Europe and Japan the profit squeeze intensified after the oil, food, and productivity shocks of the 1972-74 period. Real wages decelerated only slowly in the face of these disturbances, and much of the burden of the supply shocks was shifted to the quasi-rents of capital in the short run. In the United States, on the other hand, real wages decelerated markedly in 1973 and 1974. In Canada, a large net exporter of primary commodities, the shift in terms of trade toward these goods increased profits and the scope for growth in real wages.

Because of the external supply shocks and contractionary policies, the world economy entered the deep slump of 1974-75. The policy debate that followed is at the center of this paper. In a variety of international forums, the United States urged expansionary policy in Europe and Japan to bring about a cyclical recovery. ${ }^{2}$ The advice was largely rejected, and not merely because Europe and Japan had different tastes for unemployment and inflation in the short run. The distinct policy choices followed from differing views on many issues. Two differences were particularly important for this analysis: whether a deceleration of real wages after 1974 was a prerequisite for sustained recovery, and whether expansionary policy or austerity was the best approach to moderating real wages. European and Japanese policymakers answered the first question affirmatively. In light of the rapid growth in real wages since 1969 and the failure of real wages to decelerate sufficiently in response to the supply shocks in 197274 , they adopted a classical interpretation of the business cycle, arguing

2. In ministerial meetings of the Organisation for Economic Co-operation and Development (OECD), the United States endorsed a "locomotive" strategy, in which joint expansion of West Germany, Japan, and the United States was to lead smaller economies out of the recession. Continuing the transport metaphor, the United States later heralded a "convoy" approach, in which strong economies both large and small would lead to a world economic expansion. A good source for studying the U.S. policy position over time is the Economic Report of the President, various years. Throughout, there is a sustained argument for vigorous expansion of demand and a minimization of the risks of expansion in conditions of widespread unemployment. It is argued that monetary expansion will not lead to greater inflation, except under conditions of high utilization of capacity. A typical proposition is found in the 1978 Economic Report, pp. 114-15: "A program for achieving full recovery in the industrial economies must begin with measures to raise domestic demand and capacity utilization. Only then is sufficient investment likely to be forthcoming to achieve structural objectives. ... Both monetary and fiscal policy can make a contribution. With excess capacity everywhere, world recovery can proceed without undue concern that reasonable expansionary policies will trigger a new round of inflation." 
that real wages were too high for full employment. They pointed to low rates of profitability as a barrier to rapid expansion. Moreover, there was widespread doubt, voiced by economists in West Germany in particular, that expansionary policies could moderate real wages. And they rejected the Keynesian view that the stickiness of nominal wages made it possible for policy-induced price inflation to reduce real wages.

Different conclusions on both issues could be drawn from U.S. data. In the United States real wages slowed sharply during 1973-75, in part because of the stickiness of nominal wages, so that a classical explanation of the recession found few adherents. The deep recession in the United States was attributed to demand factors, including the failure of monetary authorities to accommodate the increase in oil prices, the transfer of wealth to OPEC, and perhaps a decline in investment demand from the complementarity between energy and capital. Expansionary fiscal and monetary policies were seen as desirable instruments to effect recovery.

In this paper I focus on the differing patterns of real wage behavior in these large industrial economies and on the resulting differences in views about macroeconomic policy. I argue that the concern in Europe and Japan about real wage behavior and profitability has been appropriate, in light of the progressive squeeze on profits until the mid-1970s. On a more subtle point, I present evidence to show that moderation in real wages could not be achieved in Europe with inflationary policy. Because of wage-setting institutions outside North America, little opportunity arises to exploit nominal wage rigidities in policymaking. To be explicit, unionized labor markets in the United States and Canada have the distinctive feature of overlapping, long-term wage agreements, which are only partially indexed. The other economies each have some combination of short-term contracts, high indexation, or centralized bargaining. According to the theory presented in the last section, these institutional arrangements lead to a relatively strong link between monetary policy and output in the United States, and to a dominant link between monetary policy and prices in the European and Japanese economies. Econometric evidence supports this conclusion, as do specific historical episodes in a number of countries.

The paper begins with a description of wage behavior in the seven large OECD economies during 1969-78. I look at the wage boom in the late 1960 s and the consequent shifts in factor shares and profitability. In some empirical work that follows, I discuss the quantitative implications of the 
shocks in terms of trade and productivity for real wages in 1973-75, and conclude that a second profit squeeze followed these disturbances in Europe and Japan. In the second section I examine the impact of the wage movements on output and profitability. The slower growth of manufacturing since 1970 appears to be closely linked to the profit squeeze following the wage boom. In the final section of the paper, I offer a brief summary of the wage-setting institutions in the various economies and an analysis of how these institutions help to shape the appropriate use of monetary policy for recovery from a profit squeeze or for control of inflation.

\section{Real Wages in Major OECD Countries, 1969-78}

This section covers the developments in real wages in the seven large OECD economies, describing the shared as well as the specific features of the patterns. The tables that follow focus mainly on four subperiods: 1962-69, 1969-73, 1973-75, and 1975-78. The 1962-69 period serves as a benchmark; in that period, the rate of growth of product wages was almost identical to that of productivity in most countries. The first and largest part of this section is devoted to 1969-73, which displayed a significant acceleration in real wages in Japan and the four European countries. I then turn to the interesting subsequent developments in 1973-75 and $1975-78$.

It is important to relate the behavior of nominal wages, $W$, both to the prices of the goods and services produced by workers and to the prices of the goods and services that they buy as consumers. With $P_{V}$ representing the deflator for value-added at factor cost, the ratio $W / P_{V}$ may be denoted as the product wage. When $W$ is divided by the consumer price deflator, $P_{c}$, the resulting ratio is the real wage. In addition, I highlight the share of labor compensation in total value-added, $W L / V P_{V}$, where $V$ is real value added and $L$, labor input, measured here as total hours worked. Thus labor's share is equivalently the ratio of the product wage to the average productivity of labor, $V / L$. Because manufacturing is the dominant sector producing tradable goods in these OECD countries, the data on compensation are also presented for manufacturing and the entire economy. Although I would like to focus separately on the private nonmanufacturing sector (the dominant producer of nontradable or "home" goods), data 
Table 1. Rates of Growth of Real and Nominal Hourly Compensation for the Manufacturing Sector and the Aggregate Economy, by Country, Selected Periods, 1962-78

Annual average, in percent

\begin{tabular}{lrrrrrrr}
\hline $\begin{array}{l}\text { Sector, measure, } \\
\text { and period }\end{array}$ & Canada & France & Germany & Italy & Japan & $\begin{array}{c}\text { United } \\
\text { Kingdom }\end{array}$ & $\begin{array}{c}\text { United } \\
\text { States }\end{array}$ \\
\hline $\begin{array}{l}\text { Manufacturing } \\
\text { Real }\end{array}$ & & & & & & & \\
$\quad$ compensation & & & & & & & \\
1962-69 & 2.9 & 4.2 & 5.1 & 6.2 & 7.6 & 2.9 & 1.9 \\
1969-73 & 3.4 & 5.9 & 7.9 & 11.7 & 9.5 & 4.3 & 1.5 \\
1973-75 & 3.8 & 6.4 & 7.2 & 7.4 & 5.2 & 6.0 & 0.8 \\
1975-78 & 2.2 & 4.4 & 4.3 & 1.9 & 0.8 & 1.3 & 2.1 \\
Nominal & & & & & & & \\
$\quad$ compensation & & & & & & & \\
1962-69 & 6.1 & 8.2 & 7.6 & 10.5 & 13.4 & 6.8 & 4.7 \\
1969-73 & 8.2 & 12.5 & 13.6 & 19.0 & 17.7 & 12.7 & 6.5 \\
1973-75 & 15.1 & 19.9 & 14.1 & 26.7 & 24.1 & 27.2 & 10.9 \\
1975-78 & 10.5 & 14.1 & 8.1 & 17.5 & 7.9 & 15.0 & 8.9 \\
Aggregate economy & & & & & & & \\
Real & & & & & & & \\
$\quad$ compensation & & & & & & & \\
1962-69 & 3.7 & 5.7 & 5.4 & 8.3 & 8.0 & 2.9 & 3.4 \\
1969-73 & 3.0 & 5.9 & 8.2 & 9.8 & 11.6 & 4.6 & 2.7 \\
1973-75 & 4.8 & 5.9 & 5.7 & 7.0 & 5.3 & 6.3 & -0.3 \\
1975-78 & 1.6 & 5.2 & 3.3 & 1.8 & 2.2 & -1.3 & 1.9 \\
Nominal & & & & & & & \\
$\quad$ compensation & & & & & & & \\
1962-69 & 6.9 & 9.8 & 8.0 & 12.6 & 13.8 & 6.8 & 6.2 \\
1969-73 & 7.8 & 12.5 & 13.9 & 17.0 & 19.9 & 13.0 & 7.8 \\
1973-75 & 9.9 & 19.3 & 12.5 & 26.3 & 24.2 & 27.7 & 9.7 \\
1975-78 & 15.0 & 7.0 & 17.4 & 9.4 & 12.0 & 8.6 \\
\hline Sours: SEap & & & & & &
\end{tabular}

Sources: See appendix A.

for such a disaggregation of most of the variables are not available or are not reliable for many countries.

\section{WAGES IN 1969-73}

Table 1 shows the sharp acceleration in nominal wages during 1969-73 in the large economies outside North America. Perry documented this phenomenon for the manufacturing sector. ${ }^{3}$ I constructed data for all

3. Perry, "Determinants of Wage Inflation." 
sectors to demonstrate that the wage boom was experienced throughout the economy. Because the manufacturing sector is typically the most unionized sector of the economy, it might be supposed that the acceleration represented a union phenomenon that was not replicated outside that sector. As explained in appendix A, the aggregate wage measures are not precise, but they indicate that the acceleration was general.

Whether a nominal wage boom translates into higher real wages depends on a number of additional factors that I discuss in subsequent sections. At this point it suffices to record that the nominal wage boom resulted in large gains in real wages (table 1) and in product wages (table 2) in countries outside North America. This is just the mirror image of Robert Gordon's finding that the acceleration in wage inflation did not lead to a comparable acceleration in price inflation; prices did not rise in proportion to the nominal wage increase. ${ }^{4}$

The data in table 2 show the growth in product wages and average productivity in the manufacturing sector and in the entire economy for each country. The product wage in manufacturing accelerates sharply during 1969-73 in all countries outside North America. The growth of labor productivity remains about the same as it was earlier or slows slightly. In the aggregate economy, $A$, product wages also accelerate, but in Germany and the United Kingdom not to the extent seen in manufacturing, $M$. In those countries $\left(W / P_{V}\right)_{M}$ accelerates more sharply than does $\left(W / P_{V}\right)_{A}$, while according to table $1, W_{M}$ and $W_{A}$ accelerate at about the same rate. Evidently, $P_{V A}$ increases more rapidly than $P_{V M}$. For reasons discussed below, more of the nominal wage push is passed on in prices outside the manufacturing sector.

The acceleration of product wages relative to productivity resulted in a shift in factor shares, particularly within the manufacturing sector. This is shown in table 3. With the exception of Japan, factor shares for the aggregate economy were stable in the 1960 s. ${ }^{5}$ Beginning with the wage boom in

4. See Gordon, "World Inflation and Monetary Accommodation," especially pp. 446-47.

5. Some evidence exists that the stability of factor shares in the sixties is greater than it was in earlier years. For data extending back to the mid-fifties, see T. P. Hill, Profits and Rates of Return (Paris: OECD, 1979). In some countries, a secular rise in labor's share is arrested in the sixties and then resumed in the seventies. From a long historical perspective, the decade of the sixties might be as remarkable for high profits and rapid growth as the seventies is for low profits and slow growth. This paper attempts to show that the change from the sixties to the seventies in real wages and profits contributed to the slowdown in output, not that the former decade was typical and the latter extraordinarily atypical. 
Table 2. Rates of Growth in the Product Wage and in Labor Productivity for the Manufacturing Sector and the Aggregate Economy, by Country, Selected Periods, 1962-78

Annual average, in percent

\begin{tabular}{lrrrrrrr}
\hline \begin{tabular}{l} 
Sector, measure, \\
\multicolumn{1}{c}{ and period }
\end{tabular} & Canada & France & Germany & Italy & Japan & $\begin{array}{c}\text { United } \\
\text { Kingdom }\end{array}$ & $\begin{array}{c}\text { United } \\
\text { States }\end{array}$ \\
\hline Manufacturing & & & & & & & \\
Product wage & & & & & & & \\
1962-69 & 5.0 & 4.8 & 5.6 & 7.4 & 10.8 & 4.6 & 3.4 \\
1969-73 & 3.6 & 7.0 & 7.5 & 9.7 & 12.6 & 5.6 & 3.6 \\
1973-75 & 0.1 & 6.2 & 6.8 & 4.4 & 0.6 & 4.6 & 0.1 \\
1975-78 & n.a. & 4.8 & $5.4^{\mathrm{a}}$ & 2.0 & 8.9 & -1.4 & 3.0 \\
Labor productivity & & & & & & & \\
1962-69 & 4.5 & 6.3 & 5.9 & 6.8 & 11.2 & 4.5 & 3.1 \\
1969-73 & 4.4 & 5.4 & 4.8 & 6.9 & 8.7 & 4.1 & 3.2 \\
1973-75 & -0.4 & 2.8 & 5.2 & 0.4 & -1.8 & -1.3 & -0.3 \\
1975-78 & 4.5 & 6.1 & 5.0 & 4.1 & 7.3 & 1.2 & 3.0 \\
& & & & & & & \\
Aggregate economy & & & & & & & \\
Product wage & & & & & & & \\
1962-69 & 3.6 & 5.1 & 5.0 & 7.8 & 8.5 & 3.2 & 3.1 \\
1969-73 & 2.0 & 5.5 & 6.3 & 7.9 & 12.2 & 3.7 & 2.6 \\
1973-75 & 1.5 & 5.1 & 4.8 & 6.0 & 8.6 & 4.9 & 0.2 \\
1975-78 & 1.8 & 5.2 & 2.7 & 1.2 & 2.7 & 1.5 & 2.3 \\
Labor productivity & & & & & & & \\
1962-69 & 3.3 & 5.2 & 5.3 & 7.4 & 9.9 & 3.1 & 2.7 \\
1969-73 & 3.2 & 5.7 & 5.2 & 6.6 & 9.1 & 3.9 & 2.6 \\
1973-75 & 0.7 & 2.6 & 4.0 & 3.0 & 3.9 & 0.7 & 0.3 \\
1975-78 & 2.0 & 5.0 & 4.5 & 1.3 & 4.1 & 2.0 & 2.1 \\
\hline
\end{tabular}

Sources: See appendix A.

a. Data are for the $1975-77$ period.

n.a. Not available.

about 1969, the share of labor compensation increased sharply in Japan and in the European countries, with the exception of France. There, a large drop in labor's share in manufacturing in 1969 (following the depreciation of the franc) balanced the upward movement from 1969 to 1973. In Japan, although the 1969-73 average shows only a small increase in labor's share, that share rose steeply in 1972-73, reaching 0.57 in manufacturing in 1973. Note that labor's share rose in the United States, although wages did not surge. Rather, a sharp deceleration of productivity after 1966 was accompanied by fairly constant growth of real wages into the early 1970s. The contrasting mechanisms through which 
Table 3. Shares of Labor Compensation in Value-Added in Manufacturing, Private Nonmanufacturing, and the Aggregate Economy, by Country, Selected Periods, 1962-78

Proportion

\begin{tabular}{|c|c|c|c|c|c|}
\hline Country and sector & $1962-64$ & $1965-68$ & $1969-73$ & $1973-75$ & $1975-78$ \\
\hline \multicolumn{6}{|l|}{ Canada } \\
\hline Manufacturing & 0.65 & 0.68 & 0.69 & 0.66 & n.a. \\
\hline Private nonmanufacturing & 0.64 & 0.62 & 0.62 & 0.60 & n.a. \\
\hline Aggregate economy & 0.68 & 0.69 & 0.69 & 0.68 & 0.69 \\
\hline \multicolumn{6}{|l|}{ France } \\
\hline Manufacturing & 0.52 & 0.52 & 0.50 & 0.54 & 0.54 \\
\hline Private nonmanufacturing & 0.72 & 0.71 & 0.71 & 0.71 & n.a. \\
\hline Aggregate economy & 0.68 & 0.67 & 0.66 & 0.68 & 0.70 \\
\hline \multicolumn{6}{|l|}{ Germany } \\
\hline Manufacturing & 0.63 & 0.62 & 0.66 & 0.70 & $0.71^{\mathrm{a}}$ \\
\hline Private nonmanufacturing & 0.72 & 0.71 & 0.70 & 0.70 & n.a. \\
\hline Aggregate economy & 0.71 & 0.70 & 0.71 & 0.73 & 0.72 \\
\hline \multicolumn{6}{|l|}{ Italy } \\
\hline Manufacturing & 0.64 & 0.62 & 0.69 & 0.70 & 0.72 \\
\hline Private nonmanufacturing & 0.71 & 0.70 & 0.72 & 0.76 & n.a. \\
\hline Aggregate economy & 0.72 & 0.71 & 0.74 & 0.77 & 0.79 \\
\hline \multicolumn{6}{|l|}{ Japan } \\
\hline Manufacturing & 0.51 & 0.51 & 0.52 & 0.59 & 0.62 \\
\hline Private nonmanufacturing & 0.75 & 0.71 & 0.73 & n.a. & n.a. \\
\hline Aggregate economy & 0.69 & 0.66 & 0.67 & 0.74 & 0.77 \\
\hline \multicolumn{6}{|l|}{ United Kingdom } \\
\hline Manufacturing & 0.70 & 0.71 & 0.75 & 0.82 & $0.84^{\mathrm{a}}$ \\
\hline Private nonmanufacturing & 0.69 & 0.69 & 0.69 & 0.68 & n.a. \\
\hline Aggregate economy & 0.72 & 0.73 & 0.74 & 0.76 & 0.77 \\
\hline \multicolumn{6}{|l|}{ United States } \\
\hline Manufacturing & 0.76 & 0.75 & 0.79 & 0.81 & 0.79 \\
\hline Private nonmanufacturing & 0.63 & 0.63 & 0.66 & 0.66 & n.a. \\
\hline Aggregate economy & 0.71 & 0.71 & 0.74 & 0.74 & 0.73 \\
\hline
\end{tabular}

Sources: See appendix A.

a. Data are for the $1975-77$ period.

n.a. Not available.

factor shares changed in the United States and Europe will be explored further below.

According to production theory, an acceleration of product wages should lower the rate of return to capital, for a given technology. The factor-price frontier defines a negative relationship between the marginal product of labor and the marginal product of capital. If the product wage 
is approximately equal to the marginal product of labor, a higher wage will be matched by a lower marginal product of capital. (With technical change, the entire factor-price frontier shifts, and a secular rise in wages need not signal anything about the rate of return to capital.) A variety of studies suggest, in fact, that rates of return to capital fell sharply during 1969-73, in line with the increase in wages and labor's share of income. ${ }^{6}$

Table 4 provides data on profitability for the $1962-76$ period. ${ }^{7}$ The data parallel that for movements in factor shares shown above. Profit rates rose in some countries and fell in others in the 1960s, but fell in the early 1970s in all countries except France.

\section{WHAT CAUSED THE 1969-73 WAGE EXPLOSION?}

The cause of the wage explosion of the early 1970s is a problem that deserves and has received extensive study. Here, I focus on the European, Japanese, and North American experiences. I summarize some results of the historical analysis to underline that the European wage developments represent events that are in large part exogenous to the short-run macroeconomic system, as typically modeled.

In the European setting, at least three factors contributed to the rapid expansion of real wages and the decline in profits in the early seventies. First, the wage behavior reflects in part a catch-up of wages that were constrained by incomes policies since the mid-sixties, and in part a reaction to unusually high profits in the late sixties. Second, the sustained period of high employment in the sixties, and specific episodes of industrial strife late in that decade, led to important institutional gains in union power

6. Accurate measures of profitability are difficult to obtain, both because of conceptual and empirical problems with capital stock data, and because of inflationinduced errors in the measurement of profits. The measure of profitability used here is capital income as a percentage of the capital stock valued at replacement cost. Under competitive conditions, sectoral profitability will approximately equal the marginal product of capital divided by the price of new capital goods relative to the price of sectoral output. Thus the rate of return declines when the marginal product of capital falls or when the relative price of capital goods increases. The latter change has had little influence on secular developments in profitability because changes in the relative price of capital goods have been small.

7. Although Hill provides valuable profit rate measures for all countries in this study, I also used detailed studies of profitability trends in individual countries. See his Profits and Rates of Return.

The concerns of note 5 apply here also. By comparison with the 1950 s, profitability in the 1960s was high (particularly in Japan and the United States) or else slowed a downward trend in the rate of return (particularly in Germany). 
Table 4. Real Rates of Return on Corporate Capital, by Country, 1962-76a

Percent

\begin{tabular}{lrrrrrrr}
\hline $\begin{array}{c}\text { Year or } \\
\text { period }\end{array}$ & Canada & France & Germany & Italy & Japan & $\begin{array}{c}\text { United } \\
\text { Kingdom }\end{array}$ & $\begin{array}{c}\text { United } \\
\text { States }\end{array}$ \\
\hline 1969 & 9.8 & 11.5 & 20.7 & 12.2 & 30.6 & 10.1 & 10.2 \\
1970 & 6.6 & 11.5 & 18.2 & 11.5 & 28.1 & 8.7 & 8.1 \\
1971 & 8.4 & 10.6 & 15.6 & 9.4 & 23.5 & 8.7 & 8.4 \\
1972 & 9.4 & 12.3 & 13.4 & 9.9 & 20.2 & 8.6 & 9.2 \\
1973 & 11.4 & 11.8 & 12.9 & n.a. & 15.7 & 7.2 & 8.6 \\
1974 & 11.4 & 10.8 & 12.7 & n.a. & 13.1 & 4.0 & 6.4 \\
1975 & 8.2 & 5.2 & 10.0 & n.a. & 13.9 & 3.4 & 6.9 \\
1976 & 8.1 & n.a. & 11.4 & n.a. & n.a. & 3.6 & 7.9 \\
Average & & & & & & & \\
$1962-64$ & 7.9 & 9.7 & 19.3 & 10.4 & 28.2 & 11.9 & 12.0 \\
$1965-69$ & 9.6 & 10.0 & 19.5 & 11.4 & 27.9 & 10.6 & 12.2 \\
$1970-73$ & 9.0 & 11.6 & 15.0 & $10.3^{\mathrm{b}}$ & 21.9 & 8.3 & 8.6 \\
$1974-76$ & 9.2 & $8.0^{\text {c }}$ & 11.4 & n.a. & $13.5^{\mathrm{c}}$ & 3.7 & 7.1 \\
\hline
\end{tabular}

Sources: Canada-A. Tarasovsky and T. G. Roseman, "Ex-Post Real Rates of Return in Canada: 1947-1976" (Ottawa: Economic Council of Canada, forthcoming in 1979); France-Mervyn King and Jacques Mairesse, "Profitability in Britain and France, A Comparative Study, 1965-1975" (Paris: National Institute of Statistics and Economic Research, 1978), table 2.1; Germany, Italy, and Japan-T. P. Hill, Profits and Rates of Return (Paris: Organisation for Economic Co-operation and Development, 1979), p. 123; United Kingdom-T. A. Clark and N. P. Williams, "Measures of Real Profitability," Bank of England Quarterly Bulletin, vol. 18 (December 1978), p. 516; and United States-Martin Feldstein and Lawrence Summers, "Is the Rate of Profit Falling?" BPEA, 1:1977, p. 216.

a. The profitability measure used here is capital income as a percentage of the capital stock measured at replacement cost. All series are pre-tax real rates of return net of depreciation. For Canada, the data refer to the manufacturing sector; for France, Germany, Italy, and Japan, the corporate manufacturing sector; for the United Kingdom, the industrial and commercial sector; and for the United States, the nonfinancial corporate sector.

b. Data are for the 1970-72 period.

c. Data are for the $1974-75$ period.

n.a. Not available.

and coverage. Third, after the increases in real wages occurred, they were partially or fully ratified by expansionary policy in the early seventies.

Soskice has provided a fascinating analysis of the wage explosion in terms of the first factor. With great attention to institutional detail, he records that European economies recovered from the recession in the midsixties with national unions comminted to incomes policies and long-term wage agreements. It is because of these policies, in his view, that labor's share was stable or actually falling throughout Europe during the 196669 period. Country by country, dissatisfaction among the rank and file with union participation in incomes policies led to the dramatic wildcat strikes in 1969-70 that heralded the wage acceleration. Indeed, the widely recognized surge in labor militancy came first, not in official union action, 
but in the critical response of workers to union inaction. A provocative aspect of the Soskice thesis is that the size of the wage settlements, "considerably greater than could be accounted for by conventional economic factors," served in part to "enable the unions to regain control of the situation, a desire common to governments and employers as well as unions."8

To explain why the modest deceleration of real wages in the late sixties should have been followed by enormous growth in real wages lasting until the mid-seventies, the second factor is important: the developments of the sixties led to important changes in the process of wage determination. For example, the upheaval in France in May 1968 brought with it the government-backed Grenelle accords that called for a large, one-time increase in real wages, and obliged employers to negotiate with unions on economic demands. In December 1968, the labor law conferred recognition for the first time on plant-based bargaining. The "hot autumn" of 1969 in Italy, tied to union negotiations in the metal sector, also created large gains in wages and longer-lasting institutional changes. The Italian Parliament enacted the " 1970 Workers' Charter" on union rights, extending union powers at the plant level. Moreover, a rapid growth of membership in Italian unions occurred during the period, from 4.5 million in 1968 to 6 million in $1973 .{ }^{\circ}$ Even more important, the three competing trade union federations in Italy embarked on a common program after 1969 , substantially strengthening the common front of the labor movement. In Germany, wildcat strikes in the steel and coal industries in 1969 led the trade unions to abandon the incomes policy that had existed since the beginning of the "concerted action" policy in 1967. "Trade unions drew more of the active union elements into their policy-making forums, steering toward a more active wage policy to demonstrate their legitimacy." ${ }^{10}$ In the United Kingdom, new institutional changes were designed to limit union power, but instead they brought forth a tremendous flexing of that power. Widespread strike activity made union power a central election issue in 1970 and presaged, under a Conservative government, the

8. David Soskice, "Strike Waves and Wage Explosions, 1968-1970: An Economic Interpretation," in Crouch and Pizzorno, eds., Resurgence of Class Conflict, vol. 2: Comparative Analyses, pp. 244-45.

9. Pietro Merli Brandini, "Italy: Creating a New Industrial Relations System from the Bottom," in Barkin, ed., Worker Militancy, p. 97.

10. Joachim Bergmann and Walther Muller-Jentsch, "The Federal Republic of Germany: Cooperative Unionism and Dual Bargaining System Challenged," in ibid., p. 260. 
1971 Industrial Relations Act. In turn, the three years under the act, until its repeal in 1974 by the new Labour government, "witnessed the most direct confrontation between the unions and the government since the General Strike of 1926."11 The period was marked by a large increase in union membership, from 42 percent of the work force in the mid-1960s to about 47 percent by 1970 .

Finally, the gains in real wages were maintained because of government support, either explicitly in the wage-setting process or through expansionary fiscal policies that maintained high employment in ways I shall discuss below.

The wage experience in Japan and the North American economies during the 1969-73 period may be explained in more prosaic economic terms. Conventional equations can track the wage changes, in contrast to the European case. ${ }^{12}$ In Japan, the rapid growth of real wages resulted largely from an excess demand for labor; demographic factors brought to a halt the migration of labor to manufacturing from other sectors. ${ }^{13}$ As will be seen in the next section, high real wages substantially slowed growth in the manufacturing sector in Japan. The high real wages did not lead to significant unemployment there, but rather to the equilibration of a tightening labor market. In the United States, as noted above, the rising labor share came about because productivity growth slowed without a commensurate slowdown in real wages. Given the small effect of unemployment on nominal wages in the United States, the increases in unemployment in the early 1970s were insufficient to bring real wages into line with lower productivity growth.

11. John F. B. Goodman, "Great Britain: Toward the Social Contract," in ibid., p. 47.

12. See Perry, "Determinants of Wage Inflation." In a variety of wage equations, a "wage explosion" dummy variable is statistically significant for the European economies, but not for Japan or the North American economies. The equations for Japan seem to track adequately for 1960-72.

13. "As the work force was gradually absorbed from agriculture, the supply of labor became increasingly unable to meet the requirements for sustaining rapid expansion, particularly in the manufacturing sector. This resulted in a significant tightening of the labor market-in the early 1970s, the ratio of jobs offered to jobs wanted (the most sensitive indicator of the Japanese labor market) doubled from an average of 100 per cent (one job offer per applicant) during the 1960s." From Kunio Saito, "The Japanese Economy in Transition," International Monetary Fund, Finance and Development, vol. 14 (June 1977), p. 38. 
WAGES IN 1973-75

As evident in table 1, the growth of real wages displayed divergent patterns among the various countries during 1973-75. In France, the economy-wide growth during that period matched the rate of 1969-73; it was substantially higher in Canada and the United Kingdom; and it was lower in Germany, Italy, Japan, and the United States. Indeed, in Japan, the United States, and Italy, the growth was lower than it had been in the 1962-69 period. During this interval, the behavior of real wages must be interpreted against the background of two important developments: a slowdown in productivity and an adverse shift in the terms of trade of the large countries associated with major price increases in food and then in oil. Those two developments "warranted" a sharp deceleration of wages, in the sense that I describe below. In the absence of that sharp deceleration, real wages in Europe and Japan continued to squeeze profits and put upward pressure on labor's share.

Both within manufacturing and in the economy as a whole, labor productivity slowed abruptly in 1973-75 (see table 2). Much of the slowdown in productivity can be attributed to the recession but, importantly, much of it cannot. Even during the recovery period of $1975-78$, productivity growth was at or below the average rates of 1962-73 in all seven countries and far below that average in Italy, Japan, and the United Kingdom. It is remarkable that the productivity "lost" during 1973-75 was not made up in the next three years. Clearly the productivity slowdown, which has been hotly discussed in the United States, is a worldwide phenomenon.

It is exceedingly difficult to separate cyclical variations from shifts in trend productivity during 1973-78. Econometric measurements of trend productivity usually rely on a notion of trend output, trend hours, or a natural rate of unemployment. ${ }^{14}$ But given the huge change in growth rates during 1973-78 compared with the previous decade, these concepts are particularly hard to measure. Precise estimates of full-employment gross domestic product are questionable because it is not clear whether large productivity gains will accompany complete recovery when (and if)

14. For a study using potential output, see William D. Nordhaus, "The Recent Productivity Slowdown," $B P E A$, 3:1972, pp. 493-536; for one using potential manhours, see George L. Perry, "Potential Output and Productivity," BPEA, 1:1977, pp. 11-47. 
that occurs in the future. To measure the trend of hours worked, as Perry has done, requires detailed demographic data that is not readily available for each country.

The average rate of productivity growth for 1973-78 can serve as a reasonable guess of "trend" productivity growth for 1973-75. Much of the cyclical variation in productivity is merely a matter of timing, with decreases in labor input lagging a slowdown in output for a few quarters. The reliance on the average of the period from 1973 to 1978 allows an interval of three years after the cyclical trough for adjustments to eliminate excess labor. ${ }^{15}$ Comparing the average annual rate of growth of GDP per hour worked in 1973-78 with that during 1962-73, a slowdown is evident in all countries, with the following magnitudes (in percentage points): Canada, 1.8; France, 1.3; Germany, 1.0; Italy, 5.1; Japan, 5.6; United Kingdom, 1.9; and United States, 1.3.

Another important force that reduced the scope for growth of real wages was the shift in the terms of trade toward imported primary commodities, mainly food and energy. The importance of the adverse shift for the growth of real wages may be measured by the movement of the deflator of GDP at factor cost, $P_{V}$, relative to the consumer price index, $P_{\sigma}$. In particular, $P_{\sigma}$ rises relative to $P_{V}$ when import prices rise more rapidly than domestic prices or when the rate of indirect taxation increases. ${ }^{16}$ In either case, when $P_{c} / P_{V}$ rises, real wages must increase less rapidly than productivity if factor shares are to remain constant. By simple algebra, labor's share, $W L / P_{V} V$, is constant when real wages, $W / P_{\sigma}$, grow at the following rate:

$$
g\left(\frac{W}{P_{C}}\right)=g\left(\frac{V}{L}\right)+g\left(\frac{P_{V}}{P_{C}}\right)
$$

15. This approximation will overestimate the 1973-75 growth rate of fullemployment productivity to the extent that $1973-75$ was characterized by a onetime productivity decline in response to the increase in energy prices. It will underestimate the productivity trend to the extent that further productivity dividends will be gained by greater cyclical recovery after 1978 .

16. I state the relationship between $P_{V}$ and $P_{C}$ in these terms because a specific decomposition of movements in $P_{C} / P_{V}$ depends on the aggregative structure of the model used. In almost any model, $P_{C} / P_{V}$ will rise when final prices of exportable goods fall relative to final prices of importable goods, or when the prices of importable intermediate goods rises relative to final prices of world goods. The relative movements of $P_{C}$ and $\boldsymbol{P}_{V}$ are described at some length in Michael Bruno and Jeffrey Sachs, "Macro-economic Adjustment with Import Price Shocks: Real and Monetary Aspects," Working Paper 340 (National Bureau of Economic Research, April 1979). 
where $g()$ is the percentage growth rate of the ratio expressed in parentheses. In fact, $P_{V} / P_{\sigma}$ had risen in all countries in 1969-73; it rose more slowly (or actually fell) during 1973-75 in most of the large economies, reducing the scope for growth of real wages.

Table 5 uses equation 1 to determine the rate of growth of real wages consistent with constant factor shares in the two subperiods, 1969-73 and 1973-75, simply by adding $g\left(P_{\nabla} / P_{\sigma}\right)$ to the trend growth of productivity in each period. I focus on trend productivity growth to abstract from the part of the productivity slowdown that is cyclically induced and presumably transitory. As above, I measure the trend growth of productivity for $1973-75$ as the average growth for 1973-78; the trend for 1969-73 is measured by the $1962-73$ average.

I make a simple attempt to separate the two major factors in the movement in $P_{V} / P_{C}$ : changes in indirect taxes and shifts in the terms of trade. The term $P_{V} / P_{C}$ can be written as $\left(P_{V} / P_{V}^{m}\right) \cdot\left(P_{V}^{m} / P_{C}\right)$, where $P_{V}$ is the deflator at factor cost, and $P_{V}^{m}$ is the deflator at market prices, inclusive of indirect taxes. In table $5, g\left(P_{V}^{m} / P_{C}\right)$ is called the terms-of-trade effect because movements in $P_{V}^{m} / P_{C}$ reflect changes in relative market prices; $g\left(P_{V} / P_{V}^{m}\right)$ is the indirect-tax effect, reflecting changes in the average indirect tax rate.

Note that the warranted growth of real wages dropped significantly after 1973 in all countries except Canada. In most countries, the slower growth of productivity has the largest effect, but the shifts in terms of trade also contribute to the warranted slowdown. In every country except Canada and the United Kingdom, $P_{V}^{m} / P_{C}$ slows down during 1973-75 relative to 1969-73. This appears in table 5 as a decline during 1973-75 in the contribution of the terms-of-trade effect to warranted growth of real wages. In Canada the deflator increases far more rapidly than consumer prices during 1973-75, reflecting Canada's special position as an exporter of primary commodities in a period when the price of crude materials rose steeply relative to final goods. Japan, the most heavily dependent of the seven on foreign sources of primary commodities, suffers the largest deterioration in terms of trade. During 1973-75, consumer prices in Japan rose more than four percentage points a year faster than the GDP deflator at market prices. In almost all countries the average rate of indirect taxation fell during 1969-75, with larger drops generally in 1973-75. These declines in tax rates moderated the needed slowdown in real wages because they lowered consumer prices relative to the net prices received by firms. A partic- 
Table 5. Rates of Growth of the Warranted Real Wage and Its Components and of Actual Real Wages for the Aggregate Economy, by Country, Selected Periods, 1969-75 Annual average, in percent

\begin{tabular}{|c|c|c|c|c|c|}
\hline \multirow[b]{3}{*}{$\begin{array}{c}\text { Country and } \\
\text { period }\end{array}$} & \multicolumn{4}{|c|}{ Warranted real wage } & \multirow[b]{3}{*}{$\begin{array}{c}\text { Actual } \\
\text { real wage }\end{array}$} \\
\hline & \multirow[b]{2}{*}{ Total } & \multicolumn{3}{|c|}{ Component } & \\
\hline & & $\begin{array}{l}\text { Productivity } \\
\text { trend }^{\mathrm{b}}\end{array}$ & $\begin{array}{c}\text { Terms of } \\
\text { trade }^{\circ}\end{array}$ & $\begin{array}{l}\text { Indirect } \\
\text { tax rate }^{\mathrm{d}}\end{array}$ & \\
\hline \multicolumn{6}{|l|}{ Canada } \\
\hline 1969-73 & 4.2 & 3.2 & 0.8 & 0.2 & 3.0 \\
\hline $1973-75$ & 4.7 & 1.5 & 2.1 & 1.1 & 4.8 \\
\hline \multicolumn{6}{|l|}{ France } \\
\hline 1969-73 & 5.7 & 5.4 & 0.0 & 0.3 & 5.9 \\
\hline 1973-75 & 4.2 & 4.0 & -0.9 & 1.1 & 5.9 \\
\hline \multicolumn{6}{|l|}{ Germany } \\
\hline $1969-73$ & 7.1 & 5.3 & 1.3 & 0.5 & 8.2 \\
\hline $1973-75$ & 5.2 & 4.3 & 0.6 & 0.3 & 5.7 \\
\hline \multicolumn{6}{|l|}{ Italy } \\
\hline $1969-73$ & 8.9 & 7.1 & 1.3 & 0.5 & 9.8 \\
\hline $1973-75$ & 3.0 & 2.0 & -0.4 & 1.4 & 7.0 \\
\hline \multicolumn{6}{|l|}{ Japan } \\
\hline $1969-73$ & 9.1 & 9.6 & -0.6 & 0.1 & 11.6 \\
\hline 1973-75 & 1.0 & 4.0 & -3.5 & 0.5 & 5.3 \\
\hline \multicolumn{6}{|l|}{ United Kingdom } \\
\hline 1969-73 & 4.2 & 3.4 & 0.0 & 0.8 & 4.6 \\
\hline $1973-75$ & 2.9 & 1.5 & 0.9 & 0.5 & 6.3 \\
\hline \multicolumn{6}{|l|}{ United States } \\
\hline $1969-73$ & 2.7 & 2.6 & 0.1 & 0.0 & 2.7 \\
\hline $1973-75$ & 0.9 & 1.4 & -0.5 & 0.0 & -0.3 \\
\hline
\end{tabular}

Sources: See appendix A.

a. The warranted increase of real wages is that increase for which factor shares remain constant, as described in the text.

b. For 1969-73, trend productivity is measured as the average of the actual growth of productivity in 1962-73; for 1973-75, it is the average of the actual growth in 1973-78.

c. Measured as the ratio of the deflator for gross domestic product at market prices to the consumer price index.

d. Measured as the ratio of the deflator for gross domestic product at factor cost to that deflator at market prices.

ularly large cut in excise and sales taxes in Canada in late 1974 illustrates this point.

In the European countries and Japan the actual growth of real wages did slow along with the warranted rate, but it continued to exceed the warranted rate and hence to shift factor shares toward labor. In the 
United States the slowdown was more than sufficient to preserve factor shares, while in Canada the warranted rate of growth of real wages rose in 1973-75 and was essentially matched by the actual rate. As tables 3 and 4 indicate, the result of the persistence in the growth of real wages was another substantial increase in labor's share and another sharp decline in the rates of return to capital in all countries outside North America.

\section{WAGES IN $1975-78$}

The 1975-78 period is a fascinating one for wage developments. It is clear that the high unemployment of the "great recession" made a substantial contribution to real wage moderation. The data of table 1 remove any notion that strong trade unions have effectively controlled real wages in recent years. Although labor's share averaged higher in 1975-78 than in 1973-75 in most countries (table 3), that shift in income distribution was halted or partially reversed by the end of the period. In the United Kingdom the drop in labor's share from 0.80 in 1975 to 0.74 in 1977 testifies to the initial success of the Labour government's incomes policy. But another burst of wage increases in 1978 dulled both that success and much of the gain in profitability; labor's share increased to 0.78 in 1978. In Germany the share of labor for the entire economy fell below its 1970 level in 1978, while within the manufacturing sector, the profit squeeze continued. In Japan the growth of real wages in manufacturing declined extraordinarily from 8 percent a year in the $1962-73$ period to 1 percent during 1975-78. But an equally sharp decline in productivity growth prevented a significant increase in profit margins until 1978.

I have more to say in the final section about how the moderation in real wages was achieved.

\section{The Linkage of Real Wages to Output and Employment}

The behavior of real wages in the industrialized economies in the 1970s has had a significant effect on output, employment, and capacity growth. High real wages and low profitability spurred the austere macroeconomic policies outside North America after 1974. Moreover, they contributed directly to sluggish growth of employment, output, and capital formation. 
Understandably, macroeconomists have tended to ignore the role of real wages in the short-run determination of output and employment. Modern disequilibrium analysis in macroeconomics shows persuasively that the real wage often plays no role in output determination. To be precise, real wages importantly determine the notional output supply of firms - that is, the desired output that would emerge if firms were not rationed in their factor or output markets. But under the "typical" Keynesian circumstance in which firms are rationed in output markets, actual output is determined by demand rather than by notional supply.

In his recent insightful discussion of disequilibrium economics, Malinvaud suggests reasons why the demand-constrained equilibria of firms will be normal in advanced economies. He also outlines circumstances that will lead to classical unemployment, the situation in which firms are producing their notional supply and the real wage is too high for full employment. The spirit of his theoretical discussion pervades this paper:

Among the many conceivable combinations of events, the one most favourable to classical unemployment occurs when there is a sudden decrease in the quantity of final output per unit of labour, and when anticipations or social tensions lead to an abnormal increase in real wages.

One may argue that such a situation built up progressively in the late sixties and early seventies in the Western world. It may be considered as partly responsible for the rather substantial level of unemployment that remained during the 1972-3 boom. It was still an important part of the picture during the 1975 sharp depression. There is serious risk that it will prevail again in the future, once the slack of aggregate demand has disappeared. ${ }^{17}$

There are imposing technical difficulties in testing for classical versus Keynesian unemployment in a particular episode. Even within the simplest disequilibrium framework in which identical firms are either all demand-rationed or all producing notional supply, it is difficult to perform econometric tests to distinguish the two cases. At a minimum, both notional demand and notional supply equations must be posited and statistically identified..$^{18} \mathrm{~A}$ major complication is introduced when the rationing occurs only in some markets, but not others, so that there is a mix of

17. E. Malinvaud, The Theory of Unemployment Reconsidered (Wiley, 1977), pp. $107-08$.

18. For a good discussion of the econometrics of disequilibrium estimation, see R. Bowden, The Econometrics of Disequilibrium, Studies in Mathematical and Managerial Economics, vol. 26 (Elsevier-North Holland, 1978). 
the classical and Keynesian cases. Finally, Malinvaud's remarks suggest a logical difficulty. Although the $1974-75$ recession probably reflected a demand-constrained situation, the high level of real wages made it likely that classical unemployment would prevail when demand was restored. The fact that firms were demand-constrained in 1975 does not eliminate the concern about excessive real wages during the recovery period.

I do not offer a rigorous econometric test for classical unemployment in the seventies. Rather, I argue that the timing of output movements in the sixties and seventies strongly points to a role for real wages in output determination and capital accumulation. The slowdown in the growth of the manufacturing sector in the early seventies and the failure of economies outside North America to recover from the 1974-75 recession are the central facts that I emphasize in what follows. To set the stage, I turn briefly to some theoretical issues.

\section{AGGREGATE SUPPLY IN THE OPEN ECONOMY}

Real wages affect aggregate supply in the open economy through many channels. In the short run, increases in real wages may induce profitmaximizing firms to reduce labor input, in order to equate the higher wage with a higher marginal product of labor, or may cause inefficient firms to shut down entirely. ${ }^{19}$ In the longer run, higher real wages and lower profitability reduce investment incentives and thus slow the growth of capacity. This channel has been analyzed in an insightful paper by Kouri. ${ }^{20}$ To illustrate these channels and to describe some policy dilemmas occurring after a boom in real wages, I introduce a standard model of the small open economy. Because the discussion rather closely follows the

19. In his classic analysis, Houthakker showed that the case of capital-labor substitution and the case of shutdowns may be indistinguishable in aggregate data. Specifically, a value-added supply function on the industry or sectoral level can emerge through aggregation over firms with fixed proportions in the short run and different capital-labor ratios. The higher wage reduces employment through the exit of firms (or smaller production units), rather than through capital-labor substitution. See H. S. Houthakker, "The Pareto Distribution and the Cobb-Douglas Production Function in Activity Analysis," Review of Economic Studies, vol. 23, no. 1 (1955), pp. 27-31.

20. Pentti J. K. Kouri, "Profitability and Growth in a Small Open Economy," in Assar Lindbeck, ed., Inflation and Unemployment in Open Economies, Studies in International Economics, vol. 5 (Amsterdam: North-Holland, 1979), pp. 129-42. 
work in Brecher, Helpman, Rødseth, and others, I avoid mathematical derivations in this discussion. ${ }^{21}$

Consider an economy that produces home goods (private nontradable goods), tradable goods (exportable and import-competing goods), and government services. The tradable-goods sector faces a perfectly elastic demand for its product at the world price, which is given as

$$
P_{Q T}=P_{Q T}^{*} \cdot E,
$$

where $P_{Q T}$ and $P_{Q T}^{*}$ are, respectively, the domestic and "world" prices of tradable goods, and $E$ is the exchange rate in units of domestic currency per unit of world currency.

Assuming that government services are not directly purchased, the consumer price level may be written as an index of the prices of home goods, $H$, and tradable goods, $T$,

$$
P_{C}=P_{Q H}^{\lambda} P_{Q T}^{(1-\lambda)},
$$

where $\lambda$ is the weight of the home goods in the consumption market basket. I ignore the intermediate goods and indirect taxes, so that sectoral output prices, $P_{Q i}$, equal the sectoral value-added deflator $P_{V i}$, and output, $Q_{i}$, equals value-added, $V_{i}$.

The unique feature of the model is the assumption that the real wage, $W_{C}$, is exogenous, perhaps fixed by powerful unions or social custom. The real wage, $W_{C}$, is a weighted geometric average of the sectoral product wages. Because $W_{G}=W / P_{\sigma}$, and $P_{V i}=P_{Q i}$, from equation 3:

$$
W_{C}=\left(W / P_{V H}\right)^{\lambda}\left(W / P_{V T}\right)^{(1-\lambda)} \text {. }
$$

At a given real wage, a decrease in the product wage in one sector must be

21. See Richard A. Brecher, "Minimum Wage Rates and the Pure Theory of International Trade," Quarterly Journal of Economics, vol. 88 (February 1974), pp. 98-116; Elhanan Helpman, "Macroeconomic Policy in a Model of International Trade with a Wage Restriction," International Economic Review, vol. 17 (June 1976), pp. 262-77; and Asbjørn R $\varnothing$ dseth, "Macroeconomic Policy in a Small Open Economy," Scandinavian Journal of Economics, vol. 81, no. 1 (1979), pp. 48-59. More recent one-sector models of the linkage between real wages and output in the open economy include Franco Modigliani and Tommaso Padoa-Schioppa, The Management of an Open Economy with "100\% Plus" Wage Indexation, Essays in International Finance, 130 (Princeton University, Department of Economics, 1978); Jacques R. Drèze and Franco Modigliani, "The Trade-off between Real Wages and Employment in an Open Economy (Belgium)" (Massachusetts Institute of Technology, Department of Economics, n.d.); and Jeffrey Sachs, "Wages, Flexible Exchange Rates, and Macroeconomic Policy," Quarterly Journal of Economics, vol. 94 (forthcoming in 1980). 
matched by an increase in the product wage in the other sector. This is important because the desired level of output by firms in each sector is a negative function of the sectoral product wage.

If firms are not rationed in the output or labor market, the profitmaximizing supply for price-taking firms requires that the marginal product of labor equal the product wage. For a fixed capital stock, $\bar{K}_{i}$, and with the conventional assumption of a value-added function, $V_{i}\left(\bar{K}_{i}, L_{i}\right)$, that is linear homogeneous and well-behaved, desired labor inputs and desired output, $V_{i}^{s}$, will be a decreasing function of the product wage,

$$
V_{i}^{s}=V_{i}^{s}\left(W / P_{V i}\right) K_{i}, \quad V_{i}^{s^{\prime}}<0 .
$$

When firms are rationed in the output market, actual $V_{i}$ will be less than $V_{i}^{s}$. In general, $V_{i} \leq V_{i}^{s}\left(W / P_{V i}\right) K_{i}$, with the strict inequality holding in the Keynesian case. Experimenting with standard production functions shows that the elasticity of $V_{i}^{s}$ with respect to $W / P_{V i}$ can be quite large. For a production function that has constant elasticity of substitution, $\sigma$, and a labor share, $\alpha$, the output elasticity is given by $\alpha \sigma /(1-\alpha)$, which might easily exceed 2.0.22

Using equation 4 and the negative relationship between sectoral product wages and output in 5, a downward-sloping supply schedule, $S$, can be derived for a given capital stock, as shown in the diagram. For a given real wage, $W_{C}$, an increase in notional output in one sector must be accompanied by a decrease in the other. A rise in $W_{\sigma}$ shifts the entire schedule to $S^{\prime}$, closer to the origin. If firms are not rationed in the output market, production will take place along the $S$ schedule (or $S^{\prime}$ schedule), at a point like $A$. With Keynesian unemployment, actual production might be inside the $S$ schedule, at a point like $A^{\prime}$. It is clear that the price ratio, $P_{V H} / P_{V T}$, increases as one moves up from point $A$ to point $B$ on the $S$ schedule. ${ }^{23}$

22. Note that a short-run elasticity of output of 2.0 for wages is not observed because firms are not always, and perhaps not typically, on their notional supply schedules.

23. As one moves up $S$, the product wage in the home sector declines, although the real wage is given. From

it follows that

$$
\frac{W}{P_{V H}}=\left(\frac{W}{P_{C}}\right)\left(\frac{P_{C}}{P_{V H}}\right)=\left(\frac{W}{P_{C}}\right)\left(\frac{P_{V T}}{P_{V H}}\right)^{1-\lambda},
$$

$$
\frac{P_{V H}}{P_{V T}}=\left(\frac{W}{P_{V H}}\right)^{-1 /(1-\lambda)}\left(\frac{W}{P_{C}}\right)^{1 /(1-\lambda)} .
$$

Thus $P_{V H} / P_{V T}$ rises as $W / P_{V H}$ falls. 


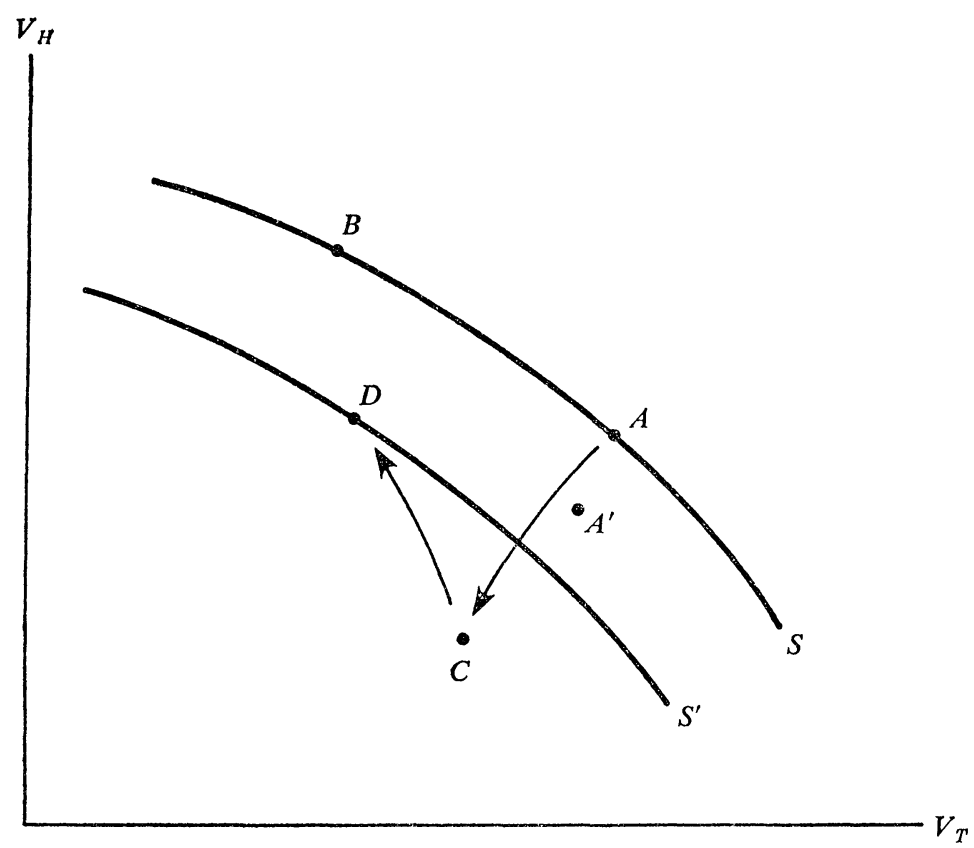

The essence of the argument about classical unemployment is that demand management can, at most, move the private economy up to the $S$ schedule, or along it, if the real wage is at $W_{C}$. If the real wage rises to $W_{C}^{\prime}$, the best that can be achieved is a point along the $S^{\prime}$ schedule. To get production back onto $S$, real wages must decline or else the capital stock or technical productivity must increase.

Four points should be made at the outset about the $S$ schedule. First, it represents output (or employment) in the private sector. Full employment can always be insured if the government sector expands enough to absorb the unemployed. This idea is the core of a model of endogenous growth of the government sector by Söderström and Viotti. ${ }^{24}$ Second, movements along the $S$ schedule involve trading off growth of one sector for contraction in another. Helpman and, implicitly, Rødseth demonstrate that expansion of the home sector at the expense of the tradable goods sector will provide a net increase in total employment in the likely case that the home sector is labor-intensive..$^{25}$ Third, if the economy has a

24. See Hans Tson Söderström and Staffan Viotti, "Money Wage Disturbances and the Endogeneity of the Public Sector in an Open Economy," in Lindbeck, ed., Inflation and Employment, pp. 71-98.

25. See Helpman, "Macroeconomic Policy in a Model of International Trade," p. 266. 
small role in world trade, so that its exporting firms face unlimited demands on the world market, government purchases of the tradable good have no effect on aggregate demand and simply show up one-for-one in the trade deficit. And fourth, expansionary demand policies will tend to raise prices of home goods relative to those of tradable goods because the latter are fixed on the world market. Whether the fiscal expansion is an increase in government employment, which raises income and demand for $V_{H}$, an income tax cut, or a direct government purchase of $V_{H}$, the effect is likely to be a movement upward along the $S$ schedule, as from $A$ to $B$.

The $S$ schedule and the conditions of aggregate demand determine short-run equilibrium of output, employment, and relative prices. The position of the $S$ schedule is a function of real wages, technology, and the capital stock in each sector. The long-run growth of aggregate supply depends fundamentally on capital accumulation, and high real wages can be an important disincentive. Previous theoretical work has explored the linkage of real wages to investment; and the main conclusions of that work can be briefly summarized.

The negative relationship between wages and capital accumulation follows from the factor-price frontier. Consider investment in the tradable goods sector, where the good is used for investment as well as for consumption. With production following a relationship $V_{T}=V_{T}\left(L_{T}, K_{T}\right)$, the factor-price frontier defines a negative relationship between $\partial V_{T} / \partial K_{T}$ and $\partial V_{T} / \partial L_{T}$, the marginal products of capital and labor. For competitive firms, $\partial V_{T} / \partial L_{T}=W / P_{V T}$ (in the absence of demand constraints). Thus there is a negative relationship between the $\partial V_{T} / \partial K_{T}$ and $W / P_{V T}$ terms. ${ }^{26}$ Most investment theories (in effect) make investment demand a function

26. By linear homogeneity, the value-added function can be written in intensive form as

Then

$$
\frac{V_{T}}{L_{T}}=f\left(\frac{K_{T}}{L_{T}}\right)
$$

$$
\frac{\partial V_{T}}{\partial K_{T}}=\frac{\partial f\left(K_{T} / L_{T}\right)}{\partial\left(K_{T} / L_{T}\right)},
$$

so that $\partial V_{T} / \partial K_{T}$ is implicitly a function of $K_{T} / L_{T}$. Similarly,

$$
\frac{\partial V_{T}}{\partial L_{T}}=f-\frac{\partial V}{\partial K_{T}} \cdot \frac{K_{T}}{L_{T}},
$$

so that $\partial V_{T} / \partial L_{T}$ is also a function of $K_{T} / L_{T}$. It is thus possible to write $\partial V_{T} / \partial K_{T}$ as an implicit (decreasing) function of $\partial V_{T} / \partial L_{T}$. For $W / P_{V T}=\partial V_{T} / \partial L_{T}$, one can obtain

$$
\frac{\partial V_{T}}{\partial K_{T}}=h\left(\frac{W}{P_{V T}}\right), \quad h^{\prime}<0 .
$$


of the difference between $\partial V_{T} / \partial K_{T}$ and the cost of capital. If the small economy takes the world cost of capital, $i^{*}$, as given, an increase in $W / P_{V T}$ lowers $\partial V_{T} / \partial K_{T}$ relative to $i^{*}$, and investment falls. Pentti Kouri has used this framework to show how a boom in real wages tends to slow capital accumulation. When his model is extended to allow for efficient operation of asset markets with rational expectations, similar conclusions are reached. ${ }^{27}$

These tools can describe the results of a boom in real wages. In the diagram, the initial effect is to shift the frontier from $S$ to $S^{\prime}$, and the economy moves from a point like $A$ to a point on $S^{\prime}$ or to one inside $S^{\prime}$, like $C$. If the government tries to maintain full employment, the shift to $C$ will induce a fiscal expansion. In the event of an increase in government employment, the economy is pushed onto the $S^{\prime}$ schedule, but with an increase in the relative price of the home good. The equilibrium is at point $D .{ }^{28}$

The expansionary policy imposes some cost. For given $W / P_{c}$, the expansion raises $P_{V H} / P_{V T}$ and thus $W / P_{V T}$. As a result, output in the tradable goods sector is likely to decline in the short run, as is capital accumulation in that sector. Finally, by ratifying the boom in real wages, the authorities forgo the chance that growth in real wages will be moderated by unemployment following the initial shock.

\section{OUTPUT AND INVESTMENT IN 1969-73}

The supply-side theory outlined above is strongly supported by the data on output behavior. Table 6 shows the growth rates of output for manufacturing, private nonmanufacturing, government services, and aggregate GDP for the seven large economies. The dominant fact after the wage boom is a slowdown in the growth of manufacturing output, which is tied to the profit squeeze in that sector at the beginning of the 1970s. In every country except France, the share of labor compensation in manufacturing rose in 1969-73 (beginning in 1967 in Canada) as shown in table 3; and the growth of that sector slowed. The profit squeeze was less severe in the nonmanufacturing sector, and the growth of output in that sector corre-

27. In a world of perfect capital mobility in which equity claims to domestic capital must earn a world rate of return, the wage boom causes an unambiguous decline in equity prices. With investment an increasing function of equity prices relative to the replacement cost of capital, the investment rate declines.

28. For details, see R $\varnothing$ dseth, "Macroeconomic Policy." 
Table 6. Rates of Growth of Real Value-Added in Manufacturing, Private

Nonmanufacturing, Government Services, and the Aggregate Economy, by Country, Selected Periods, 1963-78 a

Annual average, in percent

\begin{tabular}{|c|c|c|c|c|}
\hline $\begin{array}{l}\text { Country and } \\
\text { period }\end{array}$ & Manufacturing & $\begin{array}{c}\text { Private } \\
\text { nonmanufacturing }\end{array}$ & $\begin{array}{l}\text { Government } \\
\text { services }\end{array}$ & $\begin{array}{l}\text { Aggregate } \\
\text { economy }\end{array}$ \\
\hline \multicolumn{5}{|l|}{ Canada } \\
\hline 1963-69 & 7.1 & 5.3 & 5.6 & 5.7 \\
\hline 1969-73 & 5.0 & 6.5 & 3.9 & 5.7 \\
\hline $1973-75$ & -0.8 & 3.1 & 3.0 & 2.3 \\
\hline $1975-78$ & 5.5 & n.a. & n.a. & 3.7 \\
\hline \multicolumn{5}{|l|}{ France } \\
\hline $1963-69$ & 6.6 & 5.4 & 3.0 & 5.4 \\
\hline $1969-73$ & 6.5 & 5.6 & 3.4 & 5.6 \\
\hline $1973-75$ & 0.1 & 1.9 & 2.5 & 1.2 \\
\hline $1975-78$ & 4.5 & n.a. & n.a. & 3.9 \\
\hline \multicolumn{5}{|l|}{ Germany } \\
\hline $1963-69$ & 6.4 & 3.8 & 3.7 & 4.8 \\
\hline $1969-73$ & 4.1 & 4.6 & 5.0 & 4.4 \\
\hline 1973-75 & -2.7 & -0.5 & 3.8 & -1.0 \\
\hline $1975-78$ & 3.8 & n.a. & n.a. & 3.9 \\
\hline \multicolumn{5}{|l|}{ Italy } \\
\hline 1963-69 & 6.9 & 4.7 & 3.0 & 5.1 \\
\hline $1969-73$ & 5.7 & 3.6 & 2.7 & 4.2 \\
\hline $1973-75$ & -1.7 & n.a. & 2.7 & 0.1 \\
\hline $1975-78$ & 5.4 & n.a. & n.a. & 3.3 \\
\hline \multicolumn{5}{|l|}{ Japan } \\
\hline $1963-69$ & 14.1 & n.a. & n.a. & 10.8 \\
\hline 1969-73 & 9.8 & n.a. & n.a. & 9.2 \\
\hline 1973-75 & -7.6 & n.a. & n.a. & 0.7 \\
\hline $1975-78$ & 7.1 & n.a. & n.a. & 5.6 \\
\hline \multicolumn{5}{|l|}{ United Kingdom } \\
\hline $1963-69$ & 4.2 & 2.9 & 1.7 & 2.8 \\
\hline 1969-73 & 2.8 & 3.7 & 2.4 & 3.6 \\
\hline $1973-75$ & -3.8 & -1.1 & 2.9 & -1.1 \\
\hline $1975-78$ & 1.2 & n.a. & n.a. & 2.3 \\
\hline \multicolumn{5}{|l|}{ United States } \\
\hline $1963-69$ & 5.4 & 4.2 & 4.1 & 4.5 \\
\hline $1969-73$ & 3.2 & 4.0 & 0.8 & 3.4 \\
\hline 1973-75 & -5.9 & 0.0 & 3.2 & -1.2 \\
\hline $1975-78$ & 7.3 & n.a. & n.a. & 5.0 \\
\hline
\end{tabular}

Sources: See appendix A.

a. The first year included is 1963 rather than 1962, as elsewhere in the paper, because 1962 data for the real value-added of government services were not readily available. n.a. Not available. 
spondingly displayed a smaller slowdown. Indeed, in those countriesCanada, France, Germany, and the United Kingdom - where the share of labor compensation in nonmanufacturing did not rise in 1969-73, that sector expanded sufficiently to compensate partially or wholly for the slowdown in manufacturing. In Italy and the United States, with a rising labor's share in private nonmanufacturing, growth in that sector did not rise. Expansion of employment in the government sector in the United Kingdom and Germany was also important in maintaining the growth of aggregate output, as I describe below.

The 1969-73 slowdown in manufacturing offers a vivid view of the aggregate supply mechanism because the slowdown was clearly not a cyclical phenomenon associated with any sustained recession. In most countries, 1970 or 1971 was a recession year, but 1972 was a recovery year, and 1973 a boom year. As the table shows, real growth in GDP during 1969-73 compared to 1963-69 is either faster or maintained at about the same rate for Canada, France, Germany, and the United Kingdom. Clearly, in Canada, Germany, and the United Kingdom the manufacturing slowdown reflects a shift of production from that sector, where it had become less profitable, to other sectors where the product wage rose less steeply.

Manufacturing output displays a strong inverse relationship to lagged product wages in simple regression equations. This may seem surprising, since Bodkin and others have found no negative relationship between output and real wages in U.S. data. ${ }^{29}$ However, more recently Otani demonstrated such a negative relationship, often statistically significant, for almost all West European economies. ${ }^{30} \mathrm{I}$ have estimated simple regression equations relating manufacturing value-added to lagged product wages using annual data for 1961-74, with both variables measured as percentage deviations from an exponential trend. The regressions show a strong link in some countries between high product wages and low output in the succeeding year. The coefficients on wages were ( $t$-statistics in absolute values in parentheses): Canada, -1.18 (2.7); France, -0.07 (0.5);

29. See Ronald G. Bodkin, "Real Wages and Cyclical Variations in Employment: A Re-examination of the Evidence," Canadian Journal of Economics, vol. 2 (August 1969), pp. 353-74.

30. See Ichiro Otani, "Real Wages and Business Cycles Revisited," Review of Economics and Statistics, vol. 60 (May 1978), pp. 301-04. 
Germany, -0.85 (2.1); Italy, -0.60 (2.8); Japan, -1.63 (3.1); United Kingdom, -0.63 (1.1); United States, -0.02 (0.0). For the reason discussed earlier, the coefficients do not provide structural elasticities of output with respect to wages: the equations include periods of both Keynesian unemployment (when the coefficient should be near zero) and classical unemployment. They do give the impression that the real wage was an important determinant of output in many countries outside the United States during the 1961-74 period.

An important reason why the manufacturing slowdown did not generate a rise in aggregate unemployment in the United Kingdom and Germany is a compensating expansion of the public sector, which in effect ratified the wage explosion. In their analysis of inflation in the United Kingdom in the 1970s, Williamson and Wood make the argument that growth in the public sector was a response to macroeconomic conditions:

It seems clear enough that wage increases, rather than price increases, were the initiating factor in the intensification of inflation [in 1970]: the contrary interpretation is inconsistent with the severe squeeze on profits of recent years. ... In the absence of major change in monetary-fiscal policies or further shocks from abroad, we would have expected the wage explosion to produce a rise in unemployment to a level above the natural rate. . . Unemployment did indeed rise, peaking in the first quarter of 1972 [and] when unemployment approached the politically sensitive figure of one million, the government promptly embarked on an extremely expansionary fiscal policy. ${ }^{31}$

These events are recorded in table 7. Note that the recovery of the United Kingdom came with a sharp rise in $P_{V H} / P_{V T}$ in 1972, which I have argued is the mechanism for moving up along the $S^{\prime}$ schedule; and this further squeezed manufacturing.

The pattern for Germany is quite similar. Following the wage explosion in 1970 , the economy entered a recession in 1971, with a recovery in 1972. The OECD attributed this recession substantially to the profit squeeze following the large 1970 and 1971 wage settlements and the appreciation of the deutsche mark. ${ }^{32}$ At the end of 1971, as OECD notes, the government adopted the stance that "reflationary fiscal measures would be taken if necessary to maintain a satisfactory level of activ-

31. John Williamson and Geoffrey E. Wood, "The British Inflation: Indigenous or Imported?" American Economic Review, vol. 66 (September 1976), pp. 525-28.

32. OECD Economic Outlook, no. 10 (Paris: OECD, December 1971), pp. $57-61$. 
Table 7. Rates of Growth of Wages, Prices, Output, and the Public Sector in Germany and the United Kingdom, Selected Periods, 1962-73

Annual average, in percent

\begin{tabular}{|c|c|c|c|c|c|c|}
\hline Country and measure & $1962-69$ & $1969-73$ & 1970 & 1971 & 1972 & 1973 \\
\hline \multicolumn{7}{|l|}{ United Kingdom } \\
\hline Real wage, manufacturing & 2.9 & 4.3 & 6.4 & 4.3 & 4.8 & 1.7 \\
\hline $\begin{array}{l}\text { Value-added deflator: ratio } \\
\text { of home goods to tradable } \\
\text { goods }\end{array}$ & 2.0 & 3.0 & -1.4 & 0.6 & 4.5 & 8.8 \\
\hline $\begin{array}{l}\text { Real value-added in } \\
\text { manufacturing }\end{array}$ & 4.1 & 2.7 & 0.4 & -0.6 & 2.7 & 8.4 \\
\hline $\begin{array}{l}\text { Real value-added of } \\
\text { government services }\end{array}$ & 1.8 & 2.4 & 1.3 & 2.8 & 2.7 & 2.7 \\
\hline Real government expenditures & 1.8 & 3.1 & 1.5 & 3.0 & 4.2 & 3.7 \\
\hline \multicolumn{7}{|l|}{ Germany } \\
\hline Real wage, manufacturing & 5.1 & 7.9 & 11.9 & 7.5 & 6.0 & 6.3 \\
\hline $\begin{array}{l}\text { Value-added deflator: ratio } \\
\text { of home goods to tradable } \\
\text { goods }\end{array}$ & 1.5 & 2.3 & 0.7 & 2.9 & 3.6 & 2.0 \\
\hline $\begin{array}{l}\text { Real value-added in } \\
\text { manufacturing }\end{array}$ & 5.8 & 4.1 & 5.9 & 1.4 & 2.7 & 6.3 \\
\hline $\begin{array}{l}\text { Real value-added of } \\
\text { government services }\end{array}$ & 3.7 & 5.0 & 6.0 & 4.4 & 4.8 & 4.7 \\
\hline Real government expenditures & 3.4 & 5.3 & 4.6 & 6.3 & 4.6 & 5.5 \\
\hline
\end{tabular}

Sources: See appendix A.

ity." ${ }^{33}$ The fiscal package involved both a rapid expansion of the government sector and increased purchases of goods and services. As indicated in table 7 , the government sector and fiscal purchases grew far more rapidly during 1969-73 than during 1962-69.

The rapid increases of real wages in the late 1960s and early 1970s apparently had strong effects on capital accumulation as well as output. A slowdown in capital accumulation at the beginning of this decade has been discussed by European economists, particularly those associated with Herbert Giersch at the Institute for World Economics in Kiel, Germany. In a recent essay Giersch noted:

The present (1978/79) situation in West Germany and in countries of a similar position is characterized by a lack of investors' confidence notably in the

33. OECD Economic Outlook, no. 11 (Paris: OECD, July 1972), p. 45. 
Table 8. Rates of Growth of Net Capital Stock in Manufacturing, by Country, Selected Periods, 1962-77

Annual average, in percent

\begin{tabular}{lccc}
\hline \multicolumn{1}{c}{ Country } & $1962-70$ & $1970-73$ & $1973-77$ \\
\hline Canada & 4.4 & 4.7 & 4.8 \\
France & 6.4 & 8.3 & 7.5 \\
Germany & 8.6 & 7.2 & 4.0 \\
Italy & 5.1 & 4.7 & 3.9 \\
Japan & 14.0 & $15.2^{\mathrm{a}}$ & 9.3 \\
United Kingdom & 4.3 & 3.8 & 2.3 \\
United States & 2.7 & 2.7 & 2.8 \\
\hline
\end{tabular}

Source: Data provided by Jacques Artus, International Monetary Fund.

a. Although the rate of growth of the capital stock is very large in 1970 and 1971, it falls in 1972 and 1973. to a 12.9 percent annual rate.

international sector of the economy. . . . Between 1970 and 1971 and again after 1973 the international sector of the West German economy has grown less than would have been normal. . . . Over the period 1961 to 1977, the [rate of growth of gross fixed investment] for Germany was only 2.2 percent, exclusively due to the worse performance since 1971 [emphasis added]. ${ }^{34}$

In Germany, the share of total investment expenditure devoted to the manufacturing sector fell sharply after 1970. After averaging 27 percent during 1962-70, the share fell to 24 percent in 1972 , and then to 22 percent in both 1973 and 1974. Similarly, in the United Kingdom the share went from 25 percent during the $1962-70$ period to 21 percent during $1972-74 .^{35}$

Reliable estimates are not available of the capital stock for the seven countries in this study. Table 8 presents estimates by the International Monetary Fund of capital accumulation in manufacturing. ${ }^{36}$ The data

34. Herbert Giersch, "Aspects of Growth, Structural Change, and Employment-A Schumpeterian Perspective," paper prepared for the 1979 Kiel Conference on Macroeconomic Policies for Growth and Stability (forthcoming in Weltwirtschaftliches Archiv), pp. 24-25 in the typescript.

35. These figures were calculated from OECD national accounts statistics as the ratio of nominal gross fixed capital expenditure in manufacturing to that for all industries.

36. The data are described in Jacques R. Artus, "Measures of Potential Output in Manufacturing for Eight Countries, 1955-1978," International Monetary Fund, IMF Staff Papers, vol. 24 (March 1977), pp. 23-25. I am skeptical of the precision of the data (in particular, they do not show a deceleration in the U.S. capital stock in manufacturing after 1970), but they may offer some evidence for comparing trends across countries. 
show deceleration in the manufacturing capital stock in Germany, Italy, Japan, and the United Kingdom after 1970, and a contrasting sharp acceleration of the capital stock in France. France is the one economy that displays rising profitability and a stable share of labor income during 1969-73.

\section{OUTPUT AND INVESTMENT IN 1973-78}

The 1973-78 period began with another shift of the aggregate supply schedule toward the origin, this one initiated not by a wage explosion but by a productivity slowdown and a shift in the terms of trade. Because of a demand contraction resulting from macroeconomic policies and transfers to OPEC, significant Keynesian unemployment emerged on top of growing classical unemployment. The unemployment was certainly Keynesian in the U.S. economy, where real wages moderated in line with the productivity slowdown and the adverse shift in the terms of trade. In this episode, unlike the earlier case of the wage boom, policymakers in most countries did not ratify the profit squeeze through expansionary policy. The hope was eventually to restore the growth of the private sector by pushing down real wages relative to trend growth in productivity.

Herbert Giersch articulated this reasoning in his discussion of the German recession:

In these circumstances, economic policy has two polar options to stimulate growth and promote employment:

-lowering unit labor costs relative to other countries by restraining real wage increases and reducing the double factoral terms of trade (Option I), and -accelerating growth of total factor productivity by rejuvenating the economy and augmenting the supply of highly productive jobs (Option II). ${ }^{37}$

According to a recent study, a similar view was behind the policies of French authorities:

Since 1974, France has continued to give wage-earners and protected sectors an increasing purchasing power at rates more or less the same as in the preceding period, even though both production and productivity have fallen or stagnated. The country's economy was able to adapt ... only through ... increased international indebtedness, a reduction in profits, a curb on investment. ... [The Barre Plan] was drawn up with the aim of preparing a recovery on a healthier financial basis and the restoration of companies' profit margins.

37. Giersch, "Aspects of Growth, Structural Change, and Employment," p. 29. 
Recovery through public spending failed in 1975 because the necessary conditions for investment and consumption growth did not exist.... This explains the sudden change in government policy and its somewhat belated concentration on a stricter concept of economic management. ${ }^{38}$

After 1973, the Keynesian adjustment pattern became apparent in North America. Because real wages had little to do with the U.S. and Canadian downturn, they could be ignored in the recovery. Labor's share of income in manufacturing and throughout the economy was virtually unchanged during 1973-78. Profit rates barely fell, and according to a study by Feldstein and Summers, U.S. profitability actually rose during 1974-76 when cyclically adjusted. ${ }^{39}$ The recovery in output in the United States was vigorous, as shown in table 6. Output growth during 1975-78 was much higher than average, reflecting recovery from the 1975 cyclical trough. In Canada, the recovery was not as sustained, but the growth of manufacturing was still stronger than in Europe. Finally, in the North American economies, real capital accumulation recovered after 1975. According to table 8, growth of the capital stock in manufacturing did not slow during the recession and recovery period..$^{40}$

The OECD pointed directly to profitability as a crucial element of recovery in the United States after 1975:

[A] smaller squeeze on profit margins was reversed more rapidly and more completely in the United States [and] the restoration of profit margins was essential to the investment upswing needed to sustain the expansion in its later stages. Though still relatively weak, this private non-residential investment recovery has been more apparent in the United States than elsewhere. ${ }^{41}$

In a sense, the moderation in U.S. real wages led to expansion through both aggregate supply and demand channels. The increase in demand for investment goods was crucial for recovery, but so was the willingness of firms to supply the increased output at prevailing factor costs and output prices.

38. See Alain Bienaymé, "Incomes Policy in France," Lloyds Bank Review, no. 128 (April 1978), pp. $45-46$.

39. Martin Feldstein and Lawrence Summers, "Is the Rate of Profit Falling?" BPEA, 1:1977, pp. 211-27.

40. As mentioned above, these data probably understate the slowdown in U.S. capital accumulation during 1973-77, though the basic conclusion that the slowdown was less pronounced in North America than elsewhere has been confirmed in many analyses.

41. OECD Economic Surveys: United States (Paris: OECD, July 1978), p. 10. 
A strikingly different picture is evident in the economies of Europe and Japan. In those countries, labor's share in manufacturing rose steeply after 1973. As discussed above, growth in real wages began to moderate only after 1975 in France, Germany, and the United Kingdom. Profitability tumbled throughout Europe and Japan. And in no country outside North America has real growth since 1975 come close to earlier averages in manufacturing or the aggregate economy. Even more remarkable is the slowdown in capital accumulation in manufacturing during 1973-77, as shown in table 8.

\section{Monetary Policy and Real Wages}

To this point, the description of policy responses during the 1970s has implicitly assumed that policymakers regarded real wages as given exogenously - in effect, asking what might be accomplished for a fixed position of the $S$ schedule. In fact, policies have been adopted-and, more often, hotly debated-which were designed to induce shifts of the $S$ schedule. These include incomes policies that enforce wage moderation and payroll tax cuts that lower labor costs to the firm while preserving real take-home pay for workers. Although I have cited the role of such policies for various periods and countries, a general evaluation of them is beyond the focus of this paper.

On the other hand, I do want to explore the role of conventional monetary policy in dealing with the supply-side problem posed by high real wages and a profit squeeze. With flexible exchange rates, monetary policy is a potent vehicle for altering inflation rates, and potentially an important instrument for combating a profit squeeze or supply shock. In the models of Gordon, Phelps, and Bruno and mine, the value of monetary policy depends on its ability to affect real wages by altering the price level. ${ }^{42}$ Yet, in the late 1970s, European and Japanese policymakers rejected the view that expansionary monetary policy could ease their profit

42. For a closed economy see Edmund S. Phelps, "Commodity-Supply Shock and Full-Employment Monetary Policy," Journal of Money, Credit and Banking, vol. 10 (May 1978), pp. 206-21; and Robert J. Gordon, "Alternative Responses of Policy to External Supply Shocks," BPEA, 1:1975, pp. 183-204. For an open economy see Bruno and Sachs, "Macro-economic Adjustment with Import Price Shocks"; Modigliani and Padoa-Schioppa, "Management of an Open Economy"; and Drèze and Modigliani, "Trade-off between Real Wages and Employment." 
squeeze, arguing that rapid expansion of the money supply is purely inflationary, and has no effect on output or real wages. Contrary to the advice of U.S. authorities, they have not adopted monetary expansion as an instrument for alleviating their problems.

The uses of monetary policy seem to depend on the specific character of national wage-setting institutions. In countries whose labor market institutions make nominal wages sluggish in the short run, monetary expansion can contribute to recovery from recession; in countries in which real wages are set independently of the price level, monetary restraint can curb inflation, with little effect on output and profits. The United States seems to fall in the first category. Most other OECD economies fall in the second.

Consider a one-time increase in the money supply under flexible exchange rates. For given levels of sectoral output, nominal interest rates in the domestic economy will tend to decline. With a high degree of capital mobility, any decline in those rates below world levels will induce an incipient capital outflow, as home residents seek to trade domestic for foreign securities. The exchange rate will then depreciate until the expected future appreciation equals the interest rate differential. Regardless of the current level of employment, that depreciation will have a strong effect on the price level; prices of tradable goods and imports will rise by approximately the extent of depreciation..$^{43}$ If nominal wages are fixed, prices of tradable goods are driven up relative to the wage level, and the production of those goods is stimulated. The increased income generated in that sector will then raise the demand for home goods.

If, however, nominal wages respond to higher prices so that real wages are preserved, domestic wages and prices will eventually rise in proportion to the original increase in the money supply. Profitability in tradable and home goods will return to initial levels; no output effect will occur. The contrasting cases show that, with sluggish nominal wages, monetary policy can affect output; with rigid real wages, monetary policy works on prices. Thus, in the latter case, monetary contraction is a powerful tool for controlling inflation.

43. For a detailed theoretical analysis of the linkages among exchange rates, prices, and wages see Sachs, "Wages, Flexible Exchange Rates, and Macro-economic Policy." The empirical evidence for the connection between exchange rates and prices is discussed in Rudiger Dornbusch and Paul Krugman, "Flexible Exchange Rates in the Short Run," BPEA, 3:1976, pp. 537-75. 
It is often argued that, whenever the monetary authority can influence output and employment, it must do so by "tricking" the private sector. Why, after all, should a change in a nominal price, like a depreciation of the exchange rate, affect a real variable such as employment in the tradable-goods sector? Keynes offered a plausible explanation in the General Theory, which has been significantly enhanced in recent writings. For Keynes, it is the concerns of workers for relative rather than real wages that leads to sluggishness of nominal wages in decentralized labor markets. In periods of unemployment, workers might be willing to accept a decline (or deceleration) in real wages, but not a decline relative to other workers. The absence of the Walrasian auctioneer becomes paramount because no group will initiate a deceleration of nominal wages that all workers would accept. Fellner adapted Keynes' argument to open economies ${ }^{44} \mathrm{He}$ argued that workers may accept reductions in real wages more readily if they are engineered by currency depreciation than by nominal wage cuts, because the former leads to uniform reductions in real wages, while the latter need not.

More recently analysts have offered institutional reasons in support of Keynes' argument that the monetary authority is more effective than the private market in achieving a deceleration of real wages. Costs of bargaining, labor laws, difficulty in processing macroeconomic data, and other factors cause agents to enter into contracts without many contingencies for macroeconomic shocks. Stanley Fischer writes:

The costs that prevent the private sector insulating itself from aggregate disturbances lead also to temporarily sticky prices that produce the presumption that private sector output is not continuously optimal. Those costs are the underlying reason there is a potential role for activist monetary policy in attempting to offset aggregate disturbances. ${ }^{45}$

Thus certain institutions of the labor market, such as long-term contracts and wage indexation, should be expected to influence the degree of sluggishness of nominal wages in the short run. And they will therefore condition the role of monetary policy. For the purpose at hand, it is important that these institutions differ markedly across countries, as a result of

44. William Fellner, "Controlled Floating and the Confused Issue of Money Illusion," Banca Nazionale del Lavoro Quarterly Review, no. 106 (September 1973), pp. 206-34 (American Enterprise Institute Reprint 22).

45. Stanley Fischer, "On Activist Monetary Policy with Rational Expectations," in Fisher, ed., Rational Expectations and Economic Policy (University of Chicago Press, forthcoming), p. 24 in the typescript. 
long-term historical developments. So, too, should the role of monetary policy.

Some international differences in wage setting are described in appendix B. There I summarize the major aspects of timing in the United States and abroad and focus on the organized sector for which there is explicit information about wage-setting procedures. The timing in the organized sector has a strong influence on the nonorganized sector. Government wages are often patterned on contractual union wages, and nonunionized workers in union firms typically receive compensation in line with negotiated union settlements. According to the table, in only the United States and Canada are union sectors characterized by long-term, overlapping agreements, with low levels of wage indexation. The normal length of contracts in France, Germany, Japan, and the United Kingdom is about one year. Although these countries do not share the fully centralized bargaining systems of the Scandinavian economies, there is moderate to high synchronization of contract negotiations in Germany and Japan, and somewhat lower synchronization in France and the United Kingdom. In Japan plant-level bargaining is effectively synchronized in the "spring wage offensive" (shuntō). In the United Kingdom labor agreements are often written without fixed duration. The agreements are not legally binding and are typically subject to reopening at the request of one of the parties. Only under the Industrial Relations Act (1971-74) was there an attempt to institute legally binding agreements with obligations to maintain industrial peace for a fixed contract period. Under the recent incomes policy (1976-77), the Trade Union Congress agreed to the twelve-month rule, forbidding two contract reopenings during a twelve-month period.

Besides Canada and the United States, only Italy has long-term agreements. But in Italy the three-year bargaining cycle is basically synchronized, and extensive wage indexation (the scala mobile) allows for rapid responses of wages to changes in the price level during the contract period. The coverage of employees under the scala mobile is nearly universal in the industrial sector (including nonunion workers), though the degree of protection of real wages offered by the indexing rules has varied widely. By 1975, the elasticity of wage change with respect to price change under the index had declined to about 0.5 . An overhaul of the indexing scheme in 1975 restored the degree of indexation to more than 1.0. By 1978, it had declined again to approximately 0.85 .

The example of Germany provides the clearest case of how centralized, 


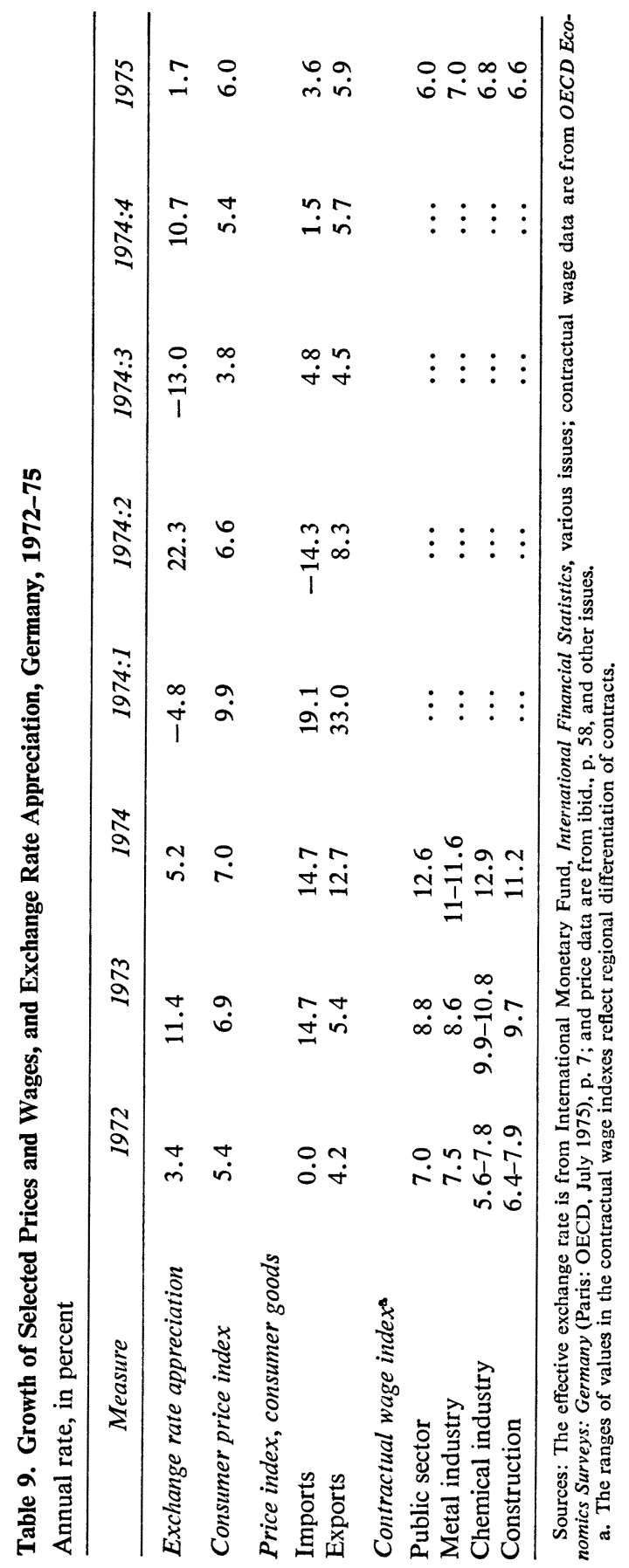


synchronized, and short-term contracts alter the role of monetary policy from fighting a profit squeeze to fighting inflation. From 1970 to 1973, annual inflation rates climbed in Germany from 3.3 percent to 6.9 percent. Contrary to popular belief, the German economy showed no special immunity to inflation. The Bundesbank pursued a contractionary monetary policy after the breakdown in March 1973 of the Smithsonian agreement of December 1971, with growth of the money stock declining from 15.4 percent in 1972 to 11.4 percent in 1973 and 9.5 percent in 1974 . Following that tightening of money, the German exchange rate appreciated sharply in 1973 and 1974. Although import and export prices showed a one-time jump after the oil price shock, the rate of inflation of consumer prices declined during the course of 1974, as shown in table 9.

At the beginning of 1974, some relaxation of Bundesbank policy was expected in light of the prospect of recession. Inflation was "widely expected to accelerate to at least 10 per cent, [and] average contractual wage increases reached about 14 per cent." ${ }_{46}^{46}$ But, according to OECD,

In pursuance of the agreed monetary policy targets, but contrary to widespread expectations, the Bundesbank did not accommodate the higher nominal wage increases by an easing of credit conditions. Consequently, businessmen were on average unable to fully pass on cost increases resulting from the high wage settlements and the upsurge in raw materials prices. The tight monetary situation produced an unexpected moderation in price inflation during 1974 [actual inflation of the consumer price index was 7 percent], to which business responded by cutting both investment and employment. ${ }^{47}$

Since wage contracts were fixed for 1974, the large nominal increases swelled real wages, with real compensation per hour climbing by 7.1 percent, after a 6.0 percent increase in 1973.

Now the annual wage round enters the story. Late in 1974, the concerted action meetings took place, with government, union, and employer representatives present. The meetings are not designed to formulate an incomes policy, but rather to enforce a "concertation of expectations," so

46. This quotation, and much of the subsequent discussion, is found in $O E C D$ Economic Surveys: Germany (Paris: OECD, July 1975), p. 7. Herbert Giersch offers a nearly identical story in American Enterprise Institute, A Discussion with Herbert Giersch: Current Problems of the West German Economy, 1976-1977, AEI Studies, 147 (AEI, 1977).

47. OECD Economic Surveys: Germany, p. 7. The OECD points out that the overexpectation of inflation was not merely due to failure to believe the monetary authorities. Rather, shifts in fiscal policy at the end of 1973 gave an indication of a more expansionary response to the developing recession. 
that the implications of governmental policy as well as private action for the macroeconomy are clearly understood by all parties. The Bundesbank warned that the low targets for monetary aggregates would be maintained throughout 1975, and that substantial unemployment would result unless nominal wage increases were sharply cut. In the words of OECD, "This message was taken seriously by employers and unions as wage increases fell drastically compared to the preceding round." ${ }^{48}$

In all major industries the increase in contractual wages plummeted in a matter of months. Each sector had a new bargaining round, so that no long-term contracts caused carry-overs from 1974. The last four rows of table 9 illustrate the deceleration in wages. This is how Germany became a country with low inflation by 1975 . The sharp appreciation of the mark resulted in only a temporary boom in real wages (which was relieved-although not adequately relieved-by 1975), so that the tight monetary policy had only a modest effect on profits and real activity. In other words, tight monetary policy did not exacerbate the profit squeeze. And the converse is also probably true: an expansionary monetary policy, announced at the concerted action meetings, would not have eased the profit squeeze. Giersch's observation is relevant:

Inflation in Germany would have much less chance [than in the United States], if any, of depressing real wage increases below the rise in distributable productivity ... for more than a year, given the inflation sensitivity of the population and the annual nation-wide wage rounds. Prospects for a long wage lag in Germany have deteriorated in comparison to the 1960s when the great post-1967 expansion, supported by longer wage contracts, ended in a series of wild cat strikes in the fall of 1969.49

Given the institutional setting, stimulative monetary policy is neither needed nor able to moderate the growth of real wages.

In the United States, on the other hand, nominal price developments importantly affect the real wage. The rise in commodity prices during 1972-74 led to a reduction in real wages because nominal wages were largely tied to decisions made before the price spurt. The inflation was an efficient way to bring about the needed decline in real wages after the relative increase in the prices of primary goods. Since 1978, another jump in inflation-induced in part by the depreciation of the U.S. dollaragain has led to a significant slowdown in the growth of real wages. The

48. Ibid., p. 8.

49. Giersch, "Aspects of Growth, Structural Change, and Employment," p. 30. 
pattern is illustrated in figure 1 : whenever current price inflation exceeds lagged wage inflation, the real wage change is typically negative. This is because the current changes in nominal wages are strongly linked to their own past value through the existence of long-term, overlapping contracts.

\section{ECONOMETRIC EVIDENCE ON WAGES}

A rigorous econometric test of short-run stickiness in nominal wages is a forbidding task..$^{50}$ The impact of long-term contracts is to make today's wage level a complicated function of price-level expectations formed over many periods. That requires the estimate of a lag structure for a variable that is itself notoriously difficult to measure. And as Griliches forcefully pointed out many years ago, even very precise econometric estimates reveal little about the lag structure of explanatory variables. ${ }^{51}$ With this disclaimer, I believe there is indirect econometric evidence to support the view of differential wage adjustment in the major countries.

The simplest way to model unindexed long-term contracts is to regard them as inducing a lagged adjustment of nominal wages to current market conditions. Suppose, for example, that new wage contracts are determined according to a Phillips curve relationship, making the increase in nominal wages a function of unemployment, $U$, and expected inflation, $p^{e}$. The existence of old contracts leads to a partial adjustment of average wage inflation to the rate set in new contracts, which can be expressed as

$$
\begin{aligned}
w-w_{-1} & =\gamma\left(w^{n}-w_{-1}\right) \\
w^{n} & =p^{e}+\phi U_{-1},
\end{aligned}
$$

where $w^{n}$ is percentage change in nominal wages in new contracts, and $w$ is average change in all contracts. With no long-term contracts, $\gamma=1$;

50. Certainly the most sophisticated attempt to link wage contracting with econometric wage equations is in John B. Taylor, "An Econometric Business Cycle Model with Rational Expectations: Some Estimation Results" (Columbia University, Department of Economics, June 1979). As a methodological investigation of certain time-series models, the paper is fascinating; as an empirical study, it is not completely successful. The demands of mathematical rigor lead the author to unrealistic assumptions of smoothness in the length and dating of contracts, though contracts are at the center of the model. It is unfortunate that conflicting demands of mathematical tractability and institutional detail are present in any investigation of wage-setting institutions.

51. See the discussion of confidence intervals around distributed lags in Zvi Griliches, "Distributed Lags: A Survey," Econometrica, vol. 35 (January 1967), pp. 16-49. 


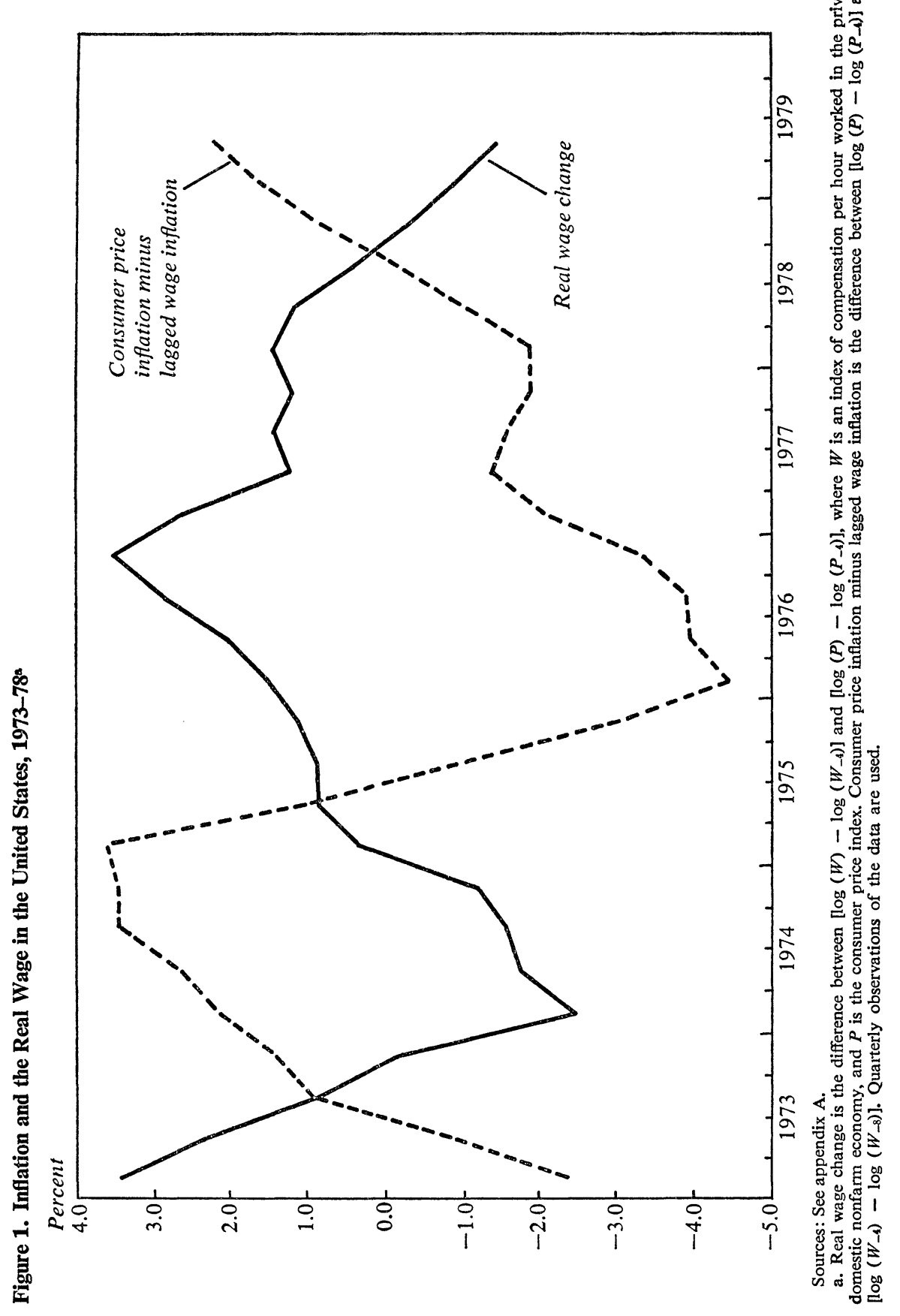


the more prevalent are long-term contracts, the closer $\gamma$ is to zero. Using equations 6 and $6 \mathrm{~A}$, expected change in real wages can be written as

$$
w-p^{e}=\gamma \phi U_{-1}-(1-\gamma)\left(p^{e}-w_{-1}\right) .
$$

With $\gamma<1$, real wages can be altered by anticipated monetary policy, which affects $p^{e}$.

Using the form $w=\beta_{0}+\beta_{1} U_{-1}+\beta_{2} p^{e}+\beta_{3} w_{-1}$, I estimated 7 for the seven economies. Rather than simply constraining $\beta_{2}+\beta_{3}$ to 1 , as suggested by 6 and $6 \mathrm{~A}$, the equations were estimated in both the unconstrained and constrained form, and the restriction was tested. The specification of $p^{e}$ is difficult. To form $p^{e}, \mathrm{I}$ adopt the procedure recommended by Sargent. ${ }^{52}$ Let $E\left(p \mid I_{-1}\right)$ represent the expectation of today's price inflation conditional on the information set, $I$, at time $t-1$. Assume that the conditional expectation is a linear function of variables, $\chi$, known at time $t-1$ and earlier, including lagged wages, prices, unemployment, and money supply: $E\left(p \mid I_{-1}\right)=\psi \chi_{-1}$. The expectations of price inflation are taken as the fitted values from a regression equation of inflation on $\chi_{-1}$. It is important in further work to try alternative estimates of $p^{e}$. Better data on expectations are probably available from sources for individual countries.

Table 10 presents equations for the seven countries with and without lagged wages. This set of equations uses the (expected) consumer price index as the price variable, though there is almost no change if the GDP deflator is used instead. The effect of changes in lagged wages on current wage inflation is remarkable in the United States. The sum of coefficients on lagged wages and current price expectations is near 1.0, but the coefficient on price expectations is four standard errors away from 1.0. Clearly the growth of real wages in the United States declines when expected inflation accelerates and rises when expected inflation decelerates. This result is apparently not due to the source of the inflation (that is, an external versus an internal shock); the lagged-wage effect is as strong using the GDP deflator as the price variable. (These results are not shown.) Because the coefficient on the lagged unemployment variable has only a small influence in the United States, this is a simple picture of real wage dynamics. The slowdown in real wage growth in 1973-74 is caused by the speedup of price inflation; the subsequent recovery of real wages

52. Thomas J. Sargent, "Rational Expectations, the Real Rate of Interest, and the Natural Rate of Unemployment," BPEA, 2:1973, pp. 429-72. 
Table 10. Estimated Wage Equations for Major OECD Countries, 1963-78

\begin{tabular}{|c|c|c|c|c|c|c|}
\hline \multirow[b]{2}{*}{ Country } & \multicolumn{3}{|c|}{ Independent variable } & \multicolumn{3}{|c|}{ Summary statistic } \\
\hline & $\begin{array}{l}\text { Labor } \\
\text { market } \\
\text { variable }\end{array}$ & $\begin{array}{l}\text { Expected } \\
\text { inflation }\end{array}$ & $\begin{array}{c}\text { Lagged } \\
\text { change } \\
\text { in wages }\end{array}$ & $\bar{R}^{2}$ & Rho & $\begin{array}{c}\text { Standard } \\
\text { error of } \\
\text { estimate }\end{array}$ \\
\hline \multirow[t]{2}{*}{ Canada } & $\begin{array}{c}0.74 \\
(1.8)\end{array}$ & $\begin{array}{l}0.83 \\
(3.3)\end{array}$ & $\cdots$ & 0.87 & $\begin{array}{l}-0.21 \\
(-0.6)\end{array}$ & 0.01 \\
\hline & $\begin{array}{c}0.44 \\
(1.0)\end{array}$ & $\begin{array}{r}0.79 \\
(3.2)\end{array}$ & $\begin{array}{r}0.18 \\
(1.0)\end{array}$ & 0.87 & $\begin{array}{l}-0.35 \\
(-1.0)\end{array}$ & 0.01 \\
\hline \multirow[t]{2}{*}{ France } & $\begin{array}{l}1.04 \\
(1.7)\end{array}$ & $\begin{array}{l}1.35 \\
(6.1)\end{array}$ & $\cdots$ & 0.56 & $\begin{array}{l}-0.32 \\
(-1.2)\end{array}$ & 0.03 \\
\hline & $\begin{array}{l}1.04 \\
(1.5)\end{array}$ & $\begin{array}{l}1.36 \\
(2.5)\end{array}$ & $\begin{array}{l}-0.00 \\
(-0.0)\end{array}$ & 0.52 & $\begin{array}{l}-0.32 \\
(-1.1)\end{array}$ & 0.03 \\
\hline \multirow[t]{2}{*}{ Germany } & $\begin{array}{c}0.50 \\
(1.7)\end{array}$ & $\begin{array}{l}0.88 \\
(1.6)\end{array}$ & $\ldots$ & 0.31 & $\begin{array}{c}0.14 \\
(0.4)\end{array}$ & 0.03 \\
\hline & $\begin{array}{c}0.61 \\
(1.7)\end{array}$ & $\begin{array}{l}0.93 \\
(1.2)\end{array}$ & $\begin{array}{l}-0.19 \\
(-0.3)\end{array}$ & 0.27 & $\begin{array}{l}0.30 \\
(0.6)\end{array}$ & 0.03 \\
\hline \multirow[t]{2}{*}{ Italy } & $\begin{array}{c}0.92 \\
(2.0)\end{array}$ & $\begin{array}{l}0.85 \\
(3.1)\end{array}$ & $\cdots$ & 0.45 & $\begin{array}{c}0.01 \\
(0.0)\end{array}$ & 0.05 \\
\hline & $\begin{array}{c}0.92 \\
(1.8)\end{array}$ & $\begin{array}{l}0.98 \\
(1.7)\end{array}$ & $\begin{array}{l}-0.14 \\
(-0.3)\end{array}$ & 0.41 & $\begin{array}{l}0.08 \\
(0.2)\end{array}$ & 0.05 \\
\hline \multirow[t]{2}{*}{ Japan } & $\begin{array}{l}1.82 \\
(2.5)\end{array}$ & $\begin{array}{l}0.72 \\
(1.9)\end{array}$ & $\ldots$ & 0.75 & $\begin{array}{c}0.47 \\
(1.0)\end{array}$ & 0.03 \\
\hline & $\begin{array}{l}1.84 \\
(3.2)\end{array}$ & $\begin{array}{c}0.82 \\
(1.9)\end{array}$ & $\begin{array}{c}0.16 \\
(0.9)\end{array}$ & 0.74 & $\begin{array}{c}0.11 \\
(0.2)\end{array}$ & 0.03 \\
\hline \multirow[t]{2}{*}{ United Kingdom } & $\begin{array}{c}1.09 \\
(2.5)\end{array}$ & $\begin{array}{l}1.22 \\
(9.8)\end{array}$ & $\cdots$ & 0.79 & $\begin{array}{l}-0.48 \\
(-1.5)\end{array}$ & 0.03 \\
\hline & $\begin{array}{c}0.90 \\
(1.8)\end{array}$ & $\begin{array}{l}1.40 \\
(6.1)\end{array}$ & $\begin{array}{l}-0.20 \\
(-0.9)\end{array}$ & 0.78 & $\begin{array}{l}-0.52 \\
(-1.7)\end{array}$ & 0.03 \\
\hline \multirow[t]{2}{*}{ United States } & $\begin{array}{l}-0.18 \\
(-1.0)\end{array}$ & $\begin{array}{r}0.11 \\
(10.4)\end{array}$ & $\ldots$ & 0.82 & $\begin{array}{l}-0.35 \\
(-1.0)\end{array}$ & 0.01 \\
\hline & $\begin{array}{c}0.14 \\
(0.9)\end{array}$ & $\begin{array}{c}0.54 \\
(4.7)\end{array}$ & $\begin{array}{l}0.43 \\
(3.7)\end{array}$ & 0.90 & $\begin{array}{l}-0.75 \\
(-3.1)\end{array}$ & 0.01 \\
\hline
\end{tabular}

Sources: See appendix A.

a. The regression equations use annual data. The labor market variable is the percentage deviation of total hours worked from trend, lagged one year, where trend hours are calculated as the peak-to-peak growth of hours worked (in logs). The series for expected inflation are the fitted values in a regression of actual inflation on lagged price inflation, lagged wage inflation, lagged changes in the money supply, and lagged values of the labor market variable, with two years of lags entered for each variable. The price variable is the consumer price index, and the wage variable is the hourly compensation in manufacturing. The numbers in parentheses are $t$-statistics. 
during 1975-77 is due to the slowdown of price inflation. Price inflation itself is basically driven by external shocks and exchange rate movements in this period. A similar pattern has occurred since mid-1978. Because of the sluggishness of nominal wage settlements, there has been a steep decline in real compensation per hour through 1979:3.

Canada and Japan show a weaker influence of lagged wage change on current rates, and the other countries display small, negative, and statistically insignificant effects. For none of the countries other than the United States is it possible to reject the hypothesis that the price expectations coefficient is unity. This result is somewhat surprising for Canada, though should be expected for the other five countries, in light of the discussion about long-term contracts. Moreover, the coefficients on the labor market variable are large in all the economies besides the United States. Real wages are determined in the United States by movements in price inflation relative to lagged wage change. Elsewhere, it appears that real wage change is a function of unemployment levels, with no role for price inflation.

The wage equations and anecdotal evidence point to more sluggishness of nominal wages in the United States than abroad. But it must be underlined that these results are preliminary, and are not particularly strong. Further econometric work is needed to test cross-equation restrictions suggested by the evidence. Can a more rapid pass-through of changes in the money supply into prices be shown for Germany than for the United States, for example? The value of this type of investigation seems clear though the work has only begun.

\section{Conclusion}

I have applied a broad brush to the complicated macroeconomic events of the 1970s. The general perspective was necessary to obtain a manageable overview of wage behavior and its implications in recent years. All data point to a clear message: the favorable growth of the 1960s was accompanied by a high and stable profit share; the slowdown in the 1970 s was preceded by a dramatic rise in real wages and a shift in income distribution toward labor in most large economies. I have argued that these facts require a modification of the Keynesian, demand-side analysis of the sluggish growth in the 1970 s. 
But a broad view can be no substitute for detailed analysis, on a country-by-country as well as a comparative basis. I should like to mention some directions in which further research is urgently needed. Most important is an econometric investigation of the aggregate supply relationships proposed in the paper. The theoretical and econometric challenge is to estimate aggregate supply equations, based on production technology, which allow for competitive supply determination over time, while permitting demand-constrained, Keynesian equilibria during a business cycle. The sophisticated methods of estimating aggregate supply schedules rely on the continuous satisfaction of first-order conditions for profit maximization. The new econometric methods of disequilibrium estimation must be combined with the procedures for estimating aggregate supply functions if the ideas in this paper are to be rigorously tested.

Second, the evidence on wage setting presents a myriad of econometric challenges for wage equations. For instance, are the wage-setting institutions sufficiently stable to identify timing lags statistically in aggregate data? I am confident that the answer is yes, but accurate tests will require far more institutional knowledge on an individual country basis. Moreover, recent theoretical models of long-term contracts must be extended to provide a more realistic basis for empirical estimation of wagesetting processes.

Finally, priority should be given to careful, institutional study of the various incomes policies applied throughout the developed economies since 1975. Important success has occurred in the last two or three years in reducing real wage settlements to levels consistent with the slower growth of productivity and the adverse terms-of-trade movements. Part of that success must be attributed to the painful ordeal of high unemployment and slow growth, but another part is from the successful application of "social contracts," payroll tax cuts, wage and price controls, and other policy instruments. It is especially important today to understand how these policy choices have fared. With the substantial hike in oil prices in 1979, these policies will again be invoked as a part of macroeconomic management in the coming years. 


\section{APPENDIX A}

\section{Primary Data: Sources and Methodology}

PRIMARY DATA SOURCES and methods of data construction are provided here that are not described elsewhere in the text.

For the manufacturing sector, almost all data are from the U.S. Bureau of Labor Statistics (BLS), Office of Productivity and Technology. The main publications are "Output per Hour, Hourly Compensation, and Unit Labor Costs in Manufacturing, Eleven Countries, 1950-1978" (BLS, July 10, 1979); "Underlying Data for Indexes of Output per Hour, Hourly Compensation, and Unit Labor Costs in Manufacturing, Eleven Countries, 1950-78" (BLS, July 1979); and "Data Sources and Methods for Indexes of Output per Hour, Hourly Compensation, and Unit Labor Costs in Manufacturing, 12 Countries" (BLS, October 1976).

For the nonmanufacturing sector (including government and private nonmanufacturing) and the aggregate economy, important data sources include National Accounts ESA, 1970-76 (Luxembourg: Statistical Office of the European Communities, 1978), and earlier issues; International Monetary Fund, International Financial Statistics, various issues; and the following OECD publications: Labour Force Statistics, 1956-1967 (Paris: 1969), and later issues; Main Economic Indicators, Historical Statistics, 1965-1975 (Paris: 1977), and later issues; and National Accounts of OECD Countries, 1965-1976 (Paris: 1977), and other issues.

The specific time-series are as follows.

\section{Manufacturing}

All series are from "Output per Hour" and "Underlying Data for Indexes." The output series is real value-added originating in manufacturing, except in Japan where it is an index of industrial production.

The hourly compensation is total compensation to employees divided by total hours worked. The data for the United States and Canada include estimates for self-employed workers. Compensation is defined in "Data Sources and Methods" to include "all payments made [to] employees, before payroll deductions of any kind, plus employer expenditures for 
legally-required insurance programs and contractual and private insurance and welfare plans [including all social security contributions]."

The value-added deflator is derived by dividing total nominal GDP originating in manufacturing by real GDP (both series from "Underlying Data for Indexes"). In Canada, Italy, Japan, and the United Kingdom the data for nominal GDP is at factor cost, while in other countries it is measured at market prices (that is, including indirect taxes). It was important to convert the market-value GDP series to a factor-cost basis. To this end, the nominal GDP series at market prices were multiplied by $(1-\operatorname{tax})$, where tax is the rate of indirect taxation for the entire economy (indirect taxes in the manufacturing sector alone were not available).

Labor's share is calculated as the ratio of total compensation to total GDP at factor cost (as described above). Except in Canada, Germany, and the United States, the compensation data exclude the self-employed. Because of data limitations, I made no attempt to adjust the compensation series in the remaining countries to include the labor income of the selfemployed. The failure to adjust the series makes little difference in Japan and the United Kingdom, where the proportion of self-employed in the total manufacturing work force is small and stable. The problem is more serious for France and Italy, where the proportion of self-employed labor declines over time, leading to an increase in the measured share of employee compensation in manufacturing GDP. (An increasing proportion of income is counted as employee compensation.) I experimented with the time-series, and it appears that this trend may account for an increase of between 1 and 2 percentage points in labor's share during 1960-78 (compared with a measured increase in Italy of 6 percentage points over the period).

Hours worked and hours per employee are from "Output per Hour."

\section{Aggregate Economy}

Output is real GDP from National Accounts of OECD Countries for 1960-70, and from OECD Economic Outlook (Paris: OECD), various issues, for more recent data.

Compensation is total employee compensation (from National Accounts of OECD Countries), with an imputation for self-employed workers. Details on the estimation process used for that imputation are available from the author on request. 
A value-added deflator at factor cost is defined as the ratio of nominal GDP at factor cost to real GDP at factor cost. Nominal GDP at factor cost is computed (from National Accounts of OECD Countries) as nominal GDP at market prices minus net indirect taxes. Real GDP at factor cost is not available in the OECD data; real GDP at market prices was used in its place (with an appropriate rescaling). The ratio of these two series yields an approximate deflator at factor cost; it is exact if net indirect taxes on an industry are, in every industry, the same proportion of value-added.

Labor's share is equal to total compensation (including the imputation for the self-employed) divided by GDP at factor cost.

Average hours per employee are from a study by Christensen, Cummings, and Jorgenson. ${ }^{53}$ Data on average hours per employee were collected for a number of countries through 1973. I updated this series by regressing it on hours per employee in manufacturing, time $(t)$, and $t^{2}$ for 1955-73, and using the fitted coefficients to extrapolate to 1978 (the series of hours per employee in manufacturing is available for 1950-78 in "Output per Hour").

Total hours worked is calculated as the product of average hours per employee and the total occupied work force (wage-and-salary workers plus the self-employed).

Hourly compensation is equal to total compensation divided by total hours worked.

\section{Nonmanufacturing Sector}

Labor's share in the private nonmanufacturing sector is calculated by subtracting from total compensation the compensation in manufacturing and government services, and dividing by nominal GDP at factor cost in the private nonmanufacturing sector. By accounting convention, compensation in the government sector, $C O M P_{G O V}$, is virtually identical with total GDP originating in the government sector, $G D P_{G O V}$. For simplicity, I measure $C O M P_{G O V}$ as $0.97\left(G D P_{G O V}\right)$.

Real output in private nonmanufacturing is simply total real GDP minus the sum of real GDP in manufacturing and real GDP in government

53. See Laurits R. Christensen, Dianne Cummings, and Dale W. Jorgenson, "Economic Growth, 1947-1973: An International Comparison," Discussion Paper 521 (Harvard University, Institute of Economic Research, December 1976). 
services. Real GDP in government services is from National Accounts of OECD Countries and, where OECD data are not available, from Yearbook of National Accounts Statistics, 1977, vol. 1, Individual Country Data (United Nations, 1978), and earlier volumes.

\section{Labor Market Tightness}

For the aggregate economy, labor market tightness is calculated as the percentage deviation of total hours worked from trend. Trend hours are calculated by linear interpolation between cyclical peaks of hours (in logs) for each country. After the most recent peak, the trend series is extended according to the growth rate between the penultimate and final peak.

\section{Consumer Price Index, Money Supply}

The consumer price index and the money supply are from International Financial Statistics. The money supply is the sum of the "money" and "quasi-money" series.

\section{APPENDIX B}

\section{Summary of Wage-Setting Institutions in Seven Industrial Economies}

THE FOLLOWING TABLE provides a summary of collective bargaining and certain other wage-setting patterns in the seven industrial economies discussed in the text. ${ }^{54}$

54. For a more detailed discussion see Barkin, ed., Worker Militan $\rightarrow$ Anne Romanis Braun, "Indexation of Wages and Salaries in Developed Economies," IMF Staff Papers, vol. 23 (March 1976), pp. 226-71; U.S. Bureau of Labor Statistics, Characteristics of Agreements Covering 1,000 Workers or More, July 1, 1972, Bulletin 1784 (Government Printing Office, 1973); International Labour Office, Collective Bargaining in Industrialised Market Economies (Geneva: ILO, 1974); and Derek Torrington, ed., Comparative Industrial Relations in Europe (London: Associated Business Programmes, 1978). 


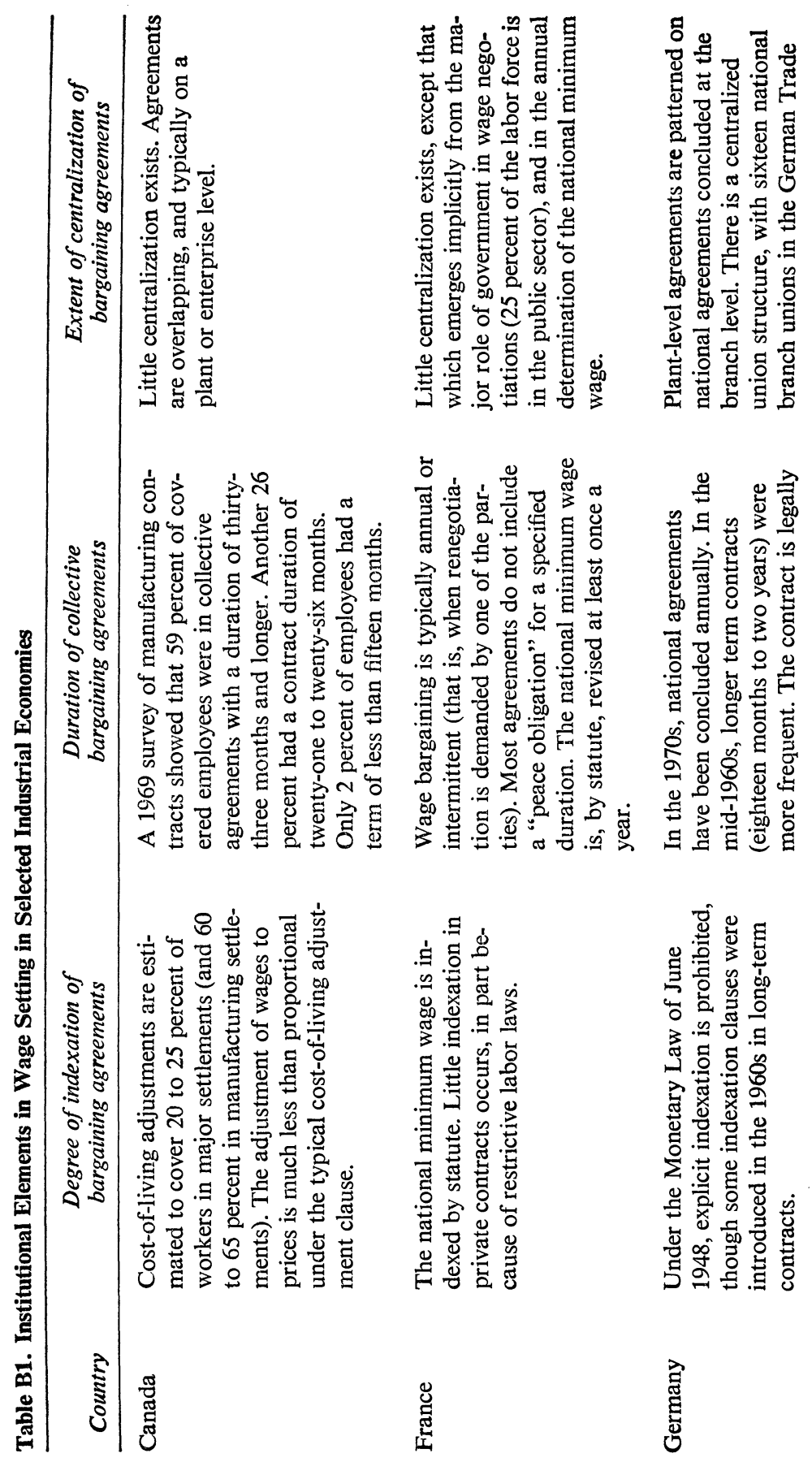




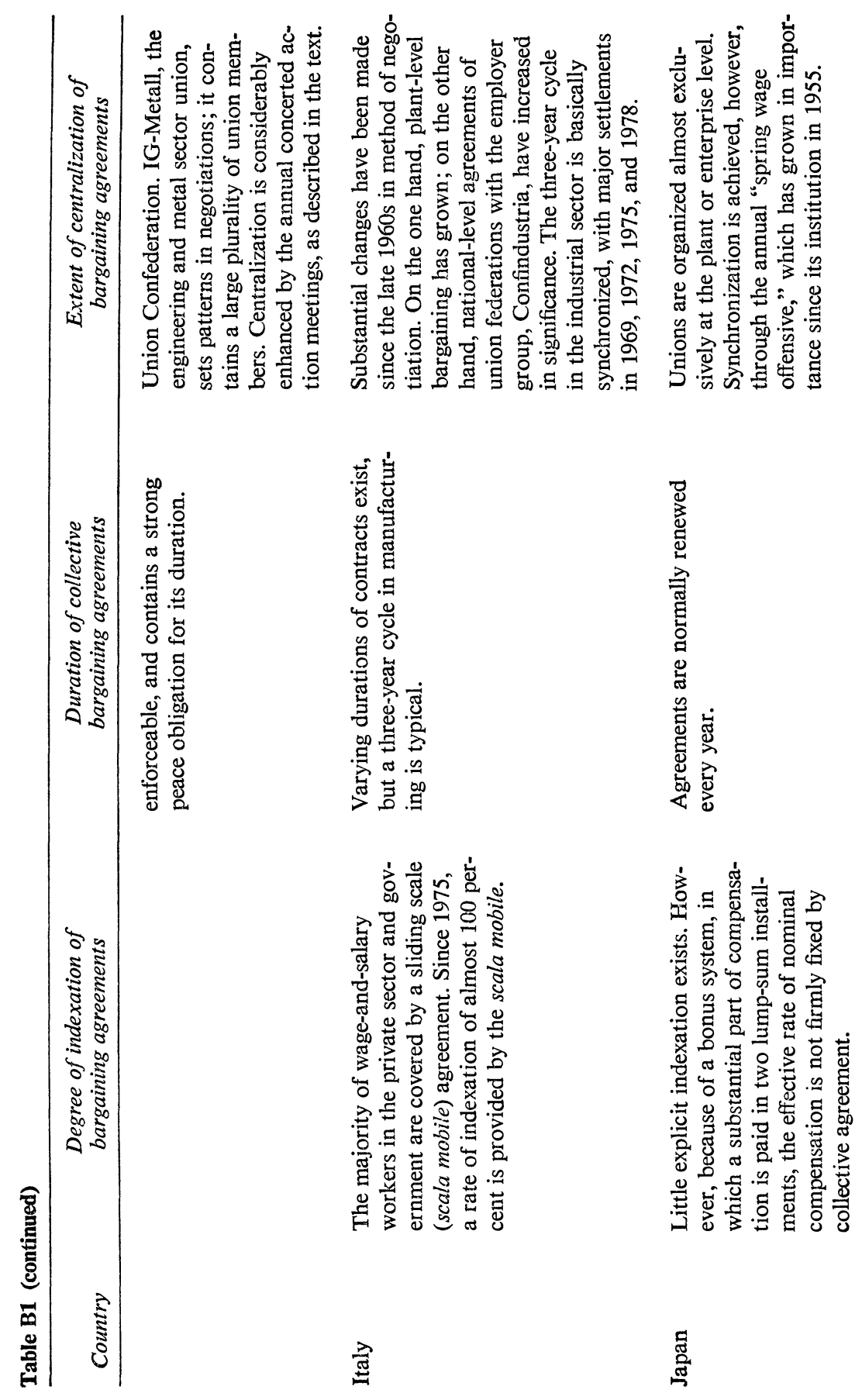



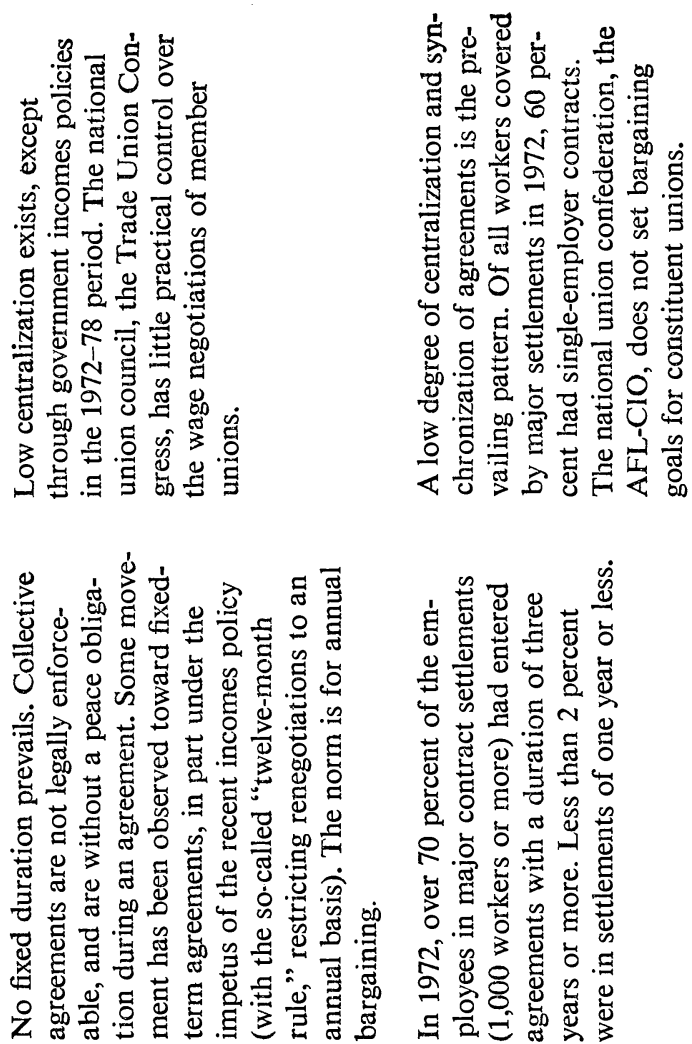

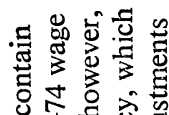

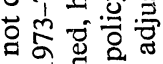

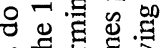

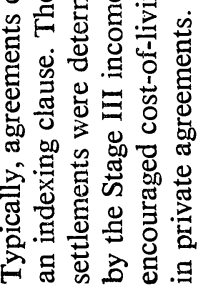

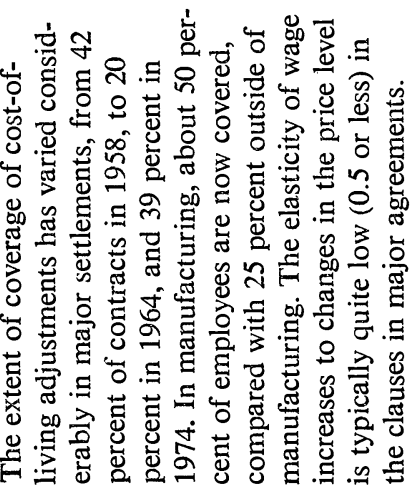

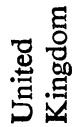
离造 


\section{Comments and Discussion}

William H. Branson: This paper by Jeffrey Sachs analyzes macroeconomic developments in the major OECD countries in the 1970s. After describing the course of wages in these countries, Sachs presents a model of a small, price-taking open economy with two sectors plus government services and then notes several features of macroeconomic developments that are consistent with the predictions of that model. Thus the theory is used to gain perspective on the data; no econometric testing is attempted except for some wage equations at the end of the paper. The major conclusions of the author are that a fundamentally exogenous increase of real wages relative to the trend of productivity occurred in most of these countries during 1969-73, and that this was followed by downward resistance of real wages after the oil crisis of 1973-74 in Europe and Japan, but not in North America. That difference accounts for the persistence of stagnation in Europe and Japan. The paper consolidates and codifies a view of the current macro problem in Europe and Japan that is becoming the conventional wisdom and that might be called "neo-structuralist." In broad terms I agree with most of Sachs' analysis; in fact I presented a paper with a colleague at a conference in Paris last month that reached broadly the same conclusions. ${ }^{1}$ And Sachs was a discussant of that paper.

I do have some points to make, though, about the details of the theory and interpretation of results. Sachs develops a price-taking model and modifies it to include the effects of terms of trade and indirect taxes. The analysis focuses on the effects of an exogenous increase in the real wage. A series of tables reveal that the actual increase in product wages and labor's share, and the fall in manufacturing's share of output and in profit

1. See William H. Branson and Julio Rotemberg, "International Adjustment with Wage Rigidities" (forthcoming in European Economic Review). 
rates in the major OECD economies during 1969-73 are all consistent with this model.

The model is now standard theory. The recent literature using such a structure includes papers by Calmfors and by Argy and Salop that assume rigid real wages, and Söderström and Viotti and Katseli-Papaefstratiou with rigid nominal wages. ${ }^{2}$ Also, McKinnon has written a paper noting the ineffectiveness of fiscal expenditure on tradable goods in this framework. ${ }^{3}$ However, all these authors have applied the model to single, small economies facing an exogenous world, while Sachs applies it to data from the major OECD countries. During the 1970s, policy was frequently coordinated in Europe, and sometimes in the entire area. Thus the three blocs of North America, Europe, and Japan probably should not be modeled as price-takers for tradable goods because that ignores the feedback from events inside these blocs to world prices. Using a small-country model here makes me uneasy. I would prefer a several-country simulation model such as that developed by Bruno and Sachs, or the two-country model used by Branson and Rotemberg. ${ }^{4}$

I have not worked through the entire paper to trace the effects of biases induced by ignoring this simultaneity, but an example is in the table comparing warranted and actual wage growth. If, in fact, wage increases push up the price of tradable manufactures, when they are taken to be exogenous in the model, the measured excess of actual over warranted increase in nominal wages will be an underestimate. Here, the bias works in favor of Sachs' argument.

The econometric results on the existence of nominal wage stickiness, or "money illusion" as it used to be called, show sticky nominal wages with

2. See Lars Calmfors, "Real Wages, Inflation, and Unemployment in the Open Economy," and Hans Tson Söderström and Staffan Viotti, "Money Wage Disturbances and the Endogeneity of the Public Sector in an Open Economy," in Assar Lindbeck, ed., Inflation and Employment in Open Economies, Studies in International Economics, vol. 5 (Amsterdam: North-Holland, 1979), pp. 41-69 and 71-98, respectively; Victor Argy and Joanne Salop, "Price and Output Effects of Monetary and Fiscal Expansion in a Two-Country World under Flexible Exchange Rates" (International Monetary Fund, May 1979); and Louka T. Katseli-Papaefstratiou, "Transmission of External Price Disturbances and the Composition of Trade," Discussion Paper 305 (Yale Growth Center, 1979).

3. See Ronald I. McKinnon, "The Limited Role of Fiscal Policy in an Open Economy," Weltwirtschaftliches Archiv (forthcoming in 1979).

4. See Michael Bruno and Jeffrey Sachs, "Supply versus Demand Approaches to the Problem of Stagflation," Working Paper 382 (National Bureau of Economic Research, 1979); and Branson and Rotemberg, "International Adjustment." 
little response to demand in the United States. In Europe, Japan, and Canada the results suggest the absence of money illusion and, instead, effectively indexed wages. They support Sachs' argument that monetary policy can affect output in the short run in the United States but not in Europe or Japan. These results are supported by the equations in Branson and Rotemberg, which use a more traditional model of adaptive wage adjustment, without relying on the estimation of expected prices with instrument variables. ${ }^{5}$

Sachs recognizes the role of weak investment in the story of 1970 s stagnation, especially in Europe, and also recognizes the need for further work in this area. I think this line of research is crucial. The slowdown in investment in Europe since the early 1970s must be reducing productivity growth and creating short-run "capital shortages" that prevent cyclical recovery from achieving full employment of labor. In a recent study, Halttunen and Warner report calculations of the cumulative shortfall in investment relative to the path of the capital stock that would be consistent with full-employment output. ${ }^{6}$ They compute the capital stock that would be required to employ the full-employment labor force for ten major OECD countries, given the trend growth in real wages since 1973. The computed stock is then compared with the actual capital stock, and the percentage shortfall of actual below full-employment capital stock in 1979 is labeled the "capital gap." These numbers run to 25 percent for industry in Japan and the Netherlands; 20 percent in France and Germany; 15 percent in Belgium-Luxembourg and the United Kingdom; 10 percent in Canada, Sweden, and Italy; and 5 percent in the United States. The cumulative effect of the investment slump in Europe and Japan is bound to be important in the analysis of the productivity slowdown, and Sachs is pointing out an important problem for further research.

Although I am mildly critical of some aspects of the analysis, I like this paper very much. It will be a good example of the $B P E A$ paradigm, a paper that is widely read by people who are trying to understand what has been happening.

5. Branson and Rotemberg, "International Adjustment."

6. See Hannu Halttunen and Dennis Warner, "A Model of Trade and Exchange Rate Projections," Working Paper 389 (National Bureau of Economic Research, August 1979). 
Robert J. Gordon: Jeffrey Sachs' paper is dazzling in the variety of talents that are brought to bear on a difficult and controversial topic of enormous scope. It is rare to find such a rich mixture in a single paper: a simple theoretical model is used to develop a novel hypothesis; painstaking effort is employed to construct the requisite data for a number of countries; and (perhaps most commendable of all) the paper not only presents intercountry differences in results but also attempts to explain them by an appeal to institutional detail. The main problems with the paper are that the empirical data do not provide strong supporting evidence for several of the basic hypotheses, and that puzzles emerge in intercountry differences in behavior that are neither explained by the author's framework nor addressed in his discussion of results.

The author's hypotheses can be divided into two groups, those applying to the early 1970s before the 1973-74 OPEC oil shock, and those applying to the postshock adjustment. For the earlier period, Sachs argues that an autonomous wage push resulted in a unique step-like increase in the share of labor compensation in national income. This increase in real wages relative to productivity in turn induced a reallocation of resources from the tradable-goods sector to the nontradable-goods sector of most economies-through the intervention of a stimulative fiscal policy to avert the higher unemployment that the excessive real wage would otherwise have caused.

For the period since 1973, the paper's emphasis shifts from the consequences of an autonomous shift in the real wage to differences among countries in the response of the real wage to an external supply shock. In the United States, sluggish adjustment in nominal wages and partial costof-living escalation create a direct negative correlation between external price shocks and the real wage, giving to monetary policy the ability to stimulate output by moving the U.S. economy out along its positively sloped aggregate supply curve. But in other nations, where cost-of-living escalation is complete (either explicitly written into contracts or implicitly as a matter of practice), the real wage is insulated from external price shocks at any given unemployment rate. This leaves slack demand as the only lever that remains for policymakers to use in forcing down real wages in tandem with productivity following a price shock, and makes the aggregate supply curve steep or vertical. And it fosters the interpretation that the reluctance of other large industrialized nations to expand in 1976-78 
resulted not from a greater distaste for inflation but rather from the fear that monetary expansion would generate a fruitless movement up a steep aggregate supply curve.

Some of Sachs' conclusions are likely to meet ready acceptance because they are neither novel nor surprising. Much of the paper can be viewed as extending and tying together conclusions previously reached in a series of comparative cross-country studies. Several of these have been presented in Brookings Papers on Economic Activity and are cited by Sachs. Although the initial study by Nordhaus of the pre- 1973 wage explosion rejected the notion of an autonomous wage push except in the case of France, Perry subsequently provided strong support for an autonomous push that he interpreted as a conflict over income shares. ${ }^{1}$ Subsequently, my eightcountry comparison confirmed the autonomous push in quarterly data. ${ }^{2}$

An autonomous push in nominal wages by itself implies nothing about real wages or income shares. Sachs devotes all his attention to the process of wage determination and completely neglects the determination of prices. His finding that the autonomous wage push in Germany, Italy, and the United Kingdom was accompanied by an increase in labor's share implies that firms did not "pass through" the wage push fully in the form of higher prices. In a previous paper I found that the wage push was not passed through and attributed the success of workers in achieving a shift in income shares to the existence of fixed exchange rates: "labor gains because its wage rate increases relative to the prices of nontraded contract goods and relative to the prices of traded goods (if the exchange rate remains constant)." 3 While this argument helps to explain why no major episode of wage push has been observed in the era of flexible exchange rates, it leaves open a question about the 1969-73 period-if exporters in all major industrial nations were faced by higher labor costs simultaneously, why were they not able to raise prices in tandem?

1. William D. Nordhaus, "The Worldwide Wage Explosion," BPEA, 2:1972, pp. 431-64; George L. Perry, "Determinants of Wage Inflation around the World," BPEA, 2:1975, pp. 403-35.

2. Robert J. Gordon, "World Inflation and Monetary Accommodation in Eight Countries," BPEA, 2:1977, pp. 409-68.

3. Robert J. Gordon, "The Demand for and Supply of Inflation," Journal of Law and Economics, vol. 18 (December 1975), p. 818 (Proceedings of a Conference, "Economic Analysis of Political Behavior," Universities-National Bureau Conference Series, 29). 
For the period before 1973, the main contribution of the paper is not in the discovery or explanation of the shift in income shares, but rather in the analysis of its consequences. The author points to the higher labor share in manufacturing as the source of a relative slowdown in the growth of manufacturing output; and he then stresses the role of fiscal policy in preventing the manufacturing slowdown from causing increased aggregate unemployment. But the story is unconvincing in many of the countries. Only the data for Germany and the United Kingdom-that is, two of the seven countries-seem to support the central interpretation. For each of the other countries there is an inconsistency. In Canada there is no meaningful shift in shares, but manufacturing output growth slows down almost as much as in Germany and more than in the United Kingdom. In France, after 1969, the product wage rises faster than productivity in manufacturing according to table 2 ; but manufacturing output essentially maintains its growth according to table 6. In Italy the share of labor increases in both manufacturing and nonmanufacturing after 1969, while the growth of output slows in both sectors; this raises questions about the source of the differential growth of labor's share in manufacturing in other countries because the Italian economy was equally open. In Japan the slowdown in manufacturing growth after 1969, shown in table 6 , is not supported by any appreciable shift in shares (table 3 ).

For the United States, the slowdown of manufacturing output presented in table 6 is sensitive to Sachs' choice of 1962 as the beginning of his initial period. Measured against a longer period, it appears that the slowdown in manufacturing, as shown in data from the national income and product accounts, was only minor during the 1969-73 period when labor's share increased, but was major in 1973-78 when labor's share was constant:

\begin{tabular}{cccc} 
& \multicolumn{3}{c}{$\begin{array}{c}\text { Annual growth rates of real } \\
\text { gross domestic product }\end{array}$} \\
\cline { 2 - 4 } Sector & $1955-69$ & $1969-73$ & $1973-78$ \\
Manufacturing & 3.7 & 3.2 & 1.8 \\
Nonmanufacturing, & & & \\
$\quad$ including government & 3.6 & 3.5 & 2.8 \\
Government & 3.4 & 0.7 & 1.5 \\
Total & 3.6 & 3.4 & 2.5
\end{tabular}


Finally, in his analysis of the 1969-73 period, Sachs may overemphasize fiscal policy and slight monetary policy. The extent of the acceleration of government GDP (table 7) for Germany and the United Kingdom seems too small to support the interpretation that fiscal policy was a major force in maintaining full employment. In contrast, I demonstrated in my BPEA paper that the money supply measured in "wage units" in the main industrialized countries outside the United States declined markedly in 1970 and then increased very rapidly in 1971 and 1972. Allowing for lags and for the fact that housing was one of the leading sectors in the expansion of 1972-73, the manufacturing recession that occurred in 1971 in Germany, Japan, Italy, and the United Kingdom and the subsequent worldwide boom in 1973 seem quite consistent with a monetarist interpretation that points to U.S. dollar outflows in 1970-71 as the primary initiating force. This qualification to Sachs' analysis does not deny his claim that policy accommodation "ratified" the 1969-70 wage push in some countries, but rather underlines the role of monetary rather than fiscal accommodation.

The sections of the paper devoted to the 1973-78 experience provide several types of evidence relevant to Herbert Giersch's hypothesis that different degrees of rigidity in real wages among countries justify the reluctance of some countries, particularly Germany and Japan, to expand their economies during the recovery beginning in 1975 . There can be no quarrel with the essential theoretical role played by real wage flexibility in the macroeconomic adjustment to supply shocks; the response of real wages and the effect of indexation were central elements in my early analysis of policy responses to supply shocks, and a more general and complete treatment of aggregate supply and real wage rigidity has recently been provided in a paper by Branson and Rotemberg. ${ }^{4}$

Because an adverse supply shock lowers the real wage relative to the product wage, any rigidity of real wages tends to push up product wages and hence labor's share. Thus the validity of the Giersch hypothesis can be tested through an inspection of the time-series behavior of labor's share. Countries with a completely flexible real wage would exhibit a constant share of labor. Countries with a completely rigid real wage that is insensitive to economic slack would exhibit a jump in labor's share at the time of the supply shock and no subsequent drop in labor's share in

4. William H. Branson and Julio Rotemberg, "International Adjustment with Wage Rigidity" (forthcoming in European Economic Review.) 
subsequent periods following the supply shock. An intermediate case would be a slowly adjusting real wage that is sensitive to economic slack, leading to a sequence in which labor's share initially jumps but then declines during a subsequent period of slack. Because averages during the 1973-75 and 1975-78 intervals disguise important movements within these intervals, it is necessary to focus on average annual change, relying on table 2 of the paper:

Change in labor's share (percentage points over interval)

$\begin{array}{lccc} & 1973 & 1975 & 1973 \\ & \text { to } 1975 & \text { to } 1978 & \text { to } 1978 \\ \text { United States } & -0.2 & 0.6 & 0.4 \\ \text { Germany } & 1.6 & -5.4 & -3.8 \\ \text { Canada } & 1.6 & -0.6 & 1.0 \\ \text { France } & 5.0 & 0.6 & 5.6 \\ \text { Italy } & 6.0 & -0.3 & 5.7 \\ \text { United Kingdom } & 8.4 & -1.5 & 6.9 \\ \text { Japan } & 9.4 & -4.2 & 5.2\end{array}$

The data are constructed by calculating the difference between annual average changes in the product wage and those in productivity for the intervals shown, and then multiplying by the number of years in the interval to obtain cumulative changes.

The seven countries are listed here in order of the increase in labor's share during the initial $1973-75$ period of supply shocks. Clearly, the United States displays the share constancy required by the Giersch hypothesis, and the four countries listed last display a marked jump in labor's share after 1973 that persisted through 1978. The downward adjustment in the growth of product wages was too small and too late in these four countries to roll back labor's share significantly. But the behavior of labor's share in Germany presents a sharp contrast. Not only did it rise relatively little from 1973 to 1975, but it dropped sharply from 1975 to 1978, falling back to its 1970 level. And it has continued to decline through the middle of 1979. In contrast to Sachs' unqualified support of Giersch, I must ask whether a trip that long was necessary. Germany could have avoided a needless restriction of its own economy as well as the world economy in 1975-78 and could have pursued a substantially more expansionary policy if it had been willing to settle for rolling back labor's share to its 1973, rather than 1970, level.

The final evidence presented is the set of time-series wage equations in 
table 10. From the accompanying discussion it would appear that the table demonstrates major differences between wage behavior in the United States and in Germany, but I think that interpretation is too hasty. The aim ultimately is to examine the effects of a monetary expansion on inflation and real output growth. The Giersch hypothesis predicts that a monetary expansion leads mainly to output growth in the United States and to inflation in Germany. But the Sachs' regression equations cannot help us trace differential impacts of money because we are given no information on the subsidiary equations used to estimate inflation expectations. The German wage equations with strong labor-market effects and unitary price-expectation coefficients are compatible with a stimulative effect of a monetary expansion on real output if the equation explaining inflation has a coefficient on monetary change that is less than unity. ${ }^{5} \mathrm{~A}$ major piece of evidence contradicting the Giersch hypothesis is the output boom in Germany from 1971 to 1973 following the 1971 monetary explosion, with only a modest acceleration of inflation.

Upon reexamination, one of the most striking aspects of Perry's paper is the amazing similarity of the best-fitting German and U.S. wage equations for his sample period, which ended in 1972, with the exception of the significance of an autonomous push variable in the German equation. This raises crucial questions that Sachs' paper does not address. Was there a radical structural shift in German wage behavior after 1972, and if so, how is it to be explained? What is the explanation of the steepness of the German Phillips curve in Sachs' equations compared to the similarity of the U.S. and German labor-market effects in Perry's results? Japan shows an even greater difference from the United States in its steeper short-run Phillips curve, another result at variance with Perry's. Overall I suspect that table 10 tells us little about real-wage rigidity, and its main result of much steeper Phillips curves outside the United States may be coming almost entirely from a few observations in the post-1972 portion of the sample period.

Finally, where does this leave the discussion of labor market institutions? In contrast to the nominal wage inertia produced by U.S. wagesetting practices, in Europe frequent and centralized bargaining seems mainly to cut loose the nominal wage from its own past values and to

5. In the reduced-form inflation equation presented for West Germany in my 1977 BPEA paper, the sum of coefficients on the current and four lagged quarterly changes of money is only 0.29 . See Gordon, "World Inflation," table 8. 
create anomalous and unpredictable patterns of behavior to bedevil econometricians. To show that institutional differences account for different patterns of serial correlation in nominal wage data is not the same thing as to show that real-wage rigidity is an important or pervasive phenomenon.

Nevertheless, despite the fact that I do not find the last part of Sachs' paper as convincing as he does, I heartily endorse his emphasis on institutional differences and demonstrate my agreement with his approach by quoting the last sentence of my $1977 B P E A$ paper:

The dramatic contrast between the volatility of changes in the wage rate in some of the Other Seven countries and the sluggish changes exhibited by the United States reminds us that we all take for granted characteristics of the U.S. economy that depend ultimately on its labor-market institutions and that would change dramatically if those institutions resembled the ones in Europe and Japan. ${ }^{6}$

Jeffrey D. Sachs: Robert Gordon disputes the view that the real-wage boom played a major role in the slowdown in manufacturing after 1970, writing that "Only the data for Germany and the United Kingdom... seem to support the central interpretation." I read the evidence differently. In Italy, he notes, labor's share rises in both sectors and output decelerates in both. This is precisely the aggregate supply effect that I outline. In France, where labor's share does not rise during 1969-73, no slowdown occurs in manufacturing output or in investment. Gordon cites correctly my tabular presentation for Japan, which shows that the average labor share during 1969-73 does not rise appreciably. But, by 1973, the level of the labor share in manufacturing (0.56) is far higher than the 1962-69 average $(0.51)$. The dramatic slowdown in the manufacturing sector is well timed with the profit squeeze. In Canada the rise in labor's share occurs in 1967-68, rather than in 1969-70, but the increase is marked; and according to the simple regression results of output on wage change, is well timed with the manufacturing slowdown. The link between product wages and output holds for most if not all of the economies. I believe that further econometric work will bear this out.

Gordon also challenges the role of high real wages during 1973-78 in the important case of Germany. He notes that, by 1978, the aggregate labor share declines to its level of 1970. But a clue to the continued reluctance of Germany to expand even after the moderation of real wages

6. Ibid., p. 449. 
is found in tables 3 and 4 . None of the reduction in labor's share came in Germany's massive manufacturing sector, and there was no relief to the squeeze on the corporate rate of return in manufacturing as late as 1976.

\section{General Discussion}

Several discussants felt that Sachs relied too heavily on a model of a small, price-taking country in interpreting macro developments during the seventies. James Duesenberry pointed to the limitations of the smallcountry paradigm in analyzing the consequences of the big wage push of the late sixties, which had occurred simultaneously in several large countries. He noted that, if all large countries experienced an identical spurt in wages, the results would be the same as for a giant closed economy. Duesenberry elaborated on the need for an analytical bridge from the small-country view to a model for a group of large countries. The relative competitiveness of the large countries in tradable goods should be taken into account. So should the opportunities for coordinated policy action by the group.

Similarly, James Tobin pointed to several aspects of expansionary monetary policy that were in fact important and that did not emerge in the small-country model. For example, the depreciation of the currency of a major country that launched an expansionary monetary policy might allow other countries to adopt more expansionary policies and thereby raise global output. Moreover, Tobin noted the existence of lags in the response of wages that enabled monetary policy to stimulate real income and real capital formation for some period, even if the real wage returned ultimately to its initial level.

On a related theme, Marina Whitman suggested that the small-country view affected Sachs' discussion of fiscal policy. In a small country, any effect of tax cuts or public spending on the tradable goods sector would be entirely a leakage. That is not the case for large countries, although even they would have less leakage if they pinpointed their fiscal stimulus on nontradable goods. Moreover, tax reductions undertaken by a large country have effects on other countries, similar to the interrelationship of monetary stimulus that Tobin identified, except that in the fiscal case it is not clear whether the effects will be positive or negative.

On the other hand, William Branson suggested that the policy implica- 
tions and general qualitative conclusions of the small-country model applied more generally whenever there were differential disturbances and independent policy responses. For example, in a model that assumes a world of two countries, monetary policy cannot affect real output in a country that has rigid real wages.

While the group was impressed by the evidence Sachs presented on the slowdown of manufacturing output in the large countries in the early 1970s, some members questioned his explanation for that development. Duesenberry recalled that some less developed countries and smaller industrial countries had emerged as stronger competitors in world trade during that period; that may have thereby curbed manufactured exports and hence total output of manufacturing in the large industrial countries. Duesenberry also pointed to a linkage from the wage push to manufacturing output via aggregate demand, rather than supply. To the extent that the spurt in wages squeezed profits, it may have curbed business fixed investment and hence the output of capital goods. Robert Lawrence pointed to currency appreciations in Japan and Germany and rapid inflation in the United Kingdom as reasons for declines in competitiveness and slowdowns in exports relative to output in these countries, especially in 1972. Lawrence also commented that home building activity had been remarkably strong in several countries at that time, contributing to the shift in the mix of output away from manufacturing and tradable goods. He felt that the housing boom was a reflection of highly stimulative monetary policies.

The wage equations in the paper generated considerable discussion. Franco Modigliani was suspicious of the use of a lagged, rather than contemporaneous, variable for unemployment. A number of discussants were concerned about the conceptual and econometric implications of specifying two effects of unemployment and of lagged wages-one direct and one that worked through price expectations. Tobin questioned the methodology that relied on coefficients from an equation estimated over an entire sample period to generate expectations within that period. This technique attributed to people information they did not have at the time they had to form their expectations. Martin Feldstein noted the possibility of updating the equations through the period to avoid that problem; but Sachs indicated that the time-series data were not adequate to permit that.

More generally, Tobin felt that the process of wage formation that Sachs described in the paper was not captured fully in his wage equations, which focused essentially on the supply side. In line with the spirit of Sachs' 
model, the demand side should be present and should include variables that determine the marginal product of labor, such as the capital stock and the prices of raw material inputs.

Hendrik Houthakker joined Tobin in calling for a structural model of the wage process that treated both supply and demand. In particular, he felt that the rapid growth of the labor force in North America was a supply influence that should be taken into account. Other factors that might have been significant in wage determination were mentioned. Michael Wachter remarked that the flows of guest workers in some European countries and flows of labor from the traditional sector to manufacturing in Japan affected the wage process in those countries. Charles Holt felt that the historical influence of public policies regarding inflation upon the institutions of wage determination in the private sector was an intriguing issue for further study.

Duesenberry, Arthur Okun, and George Perry saw various ways in which the stress on the intractability of real wages submerged considerations about demand and inflation that they considered important. Duesenberry suggested that the state of global demand influenced the behavior of real wages. With sufficiently strong global demand, a spurt in nominal wages would be more likely to be passed through into prices and thus less likely to sustain a higher real wage. Okun noted that, in Sachs' view of wage determination in Europe and Japan, reductions in indirect taxes were superior to monetary policy as an instrument; they could raise output and reduce inflation at the same time by raising real wages relative to product wages. Perry emphasized that the reluctance of policymakers in many countries to adopt stimulative monetary policy reflected a fear of the resultant inflation (especially through a depreciation of the currency) rather than any perception of rigid real wages.

Sachs responded to criticisms of his treatment of demand-management policies. He suggested that there is really less disagreement than appears because many of the comments explicitly or implicitly recognized that a demand expansion is most effective if it leads to a moderation of real wages. The important issue in this regard is whether strong demand can slow real wages by allowing a larger pass-through of nominal wage increases into prices. Sachs reiterated that a higher pass-through would likely lead to a further round of nominal wage increases, thus maintaining real wage growth, particularly in countries with widespread wage indexation or frequent bargaining. 